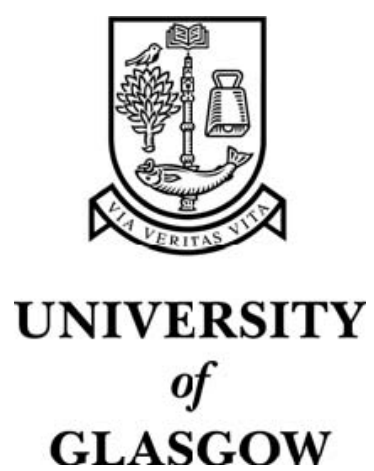

Danbolt, J. (2000) Cross-border acquisitions into the UK: an analysis of target company returns. Accounting, Accountability and Performance 6(2):pp. 27-62.

http://eprints.gla.ac.uk/3694/ 


\title{
CROSS-BORDER ACQUISITIONS INTO THE UK \\ - AN ANALYSIS OF TARGET COMPANY RETURNS
}

\author{
Jo Danbolt \\ Lecturer in Finance \\ University of Glasgow
}

\section{Address for correspondence:}

Department of Accounting and Finance, University of Glasgow, 65-73 Southpark Avenue, Glasgow G12 8LE, United Kingdom. Tel: +44 (0)141 330 6289; Fax: +44 (0)141 330 4442; E-mail: j.danbolt@accfin.gla.ac.uk

\begin{abstract}
In this paper we investigate whether there is evidence of a target company cross-border effect by comparing the premium for those companies acquired by other UK companies with the premium for those companies acquired by non-UK firms. Using data for the period 1986-1991, it is found that target company shareholders gain significantly more from crossborder than from domestic acquisitions. The cross-border effect appears to be partly attributable to a significantly higher proportion of cross-border than domestic bids being full cash offer, and target company shareholders are found to gain significantly more from cash than from equity offers. However, even after controlling for these and other bid characteristics, the target company cross-border effect remains highly significant, amounting to somewhere between 6.02 and 9.17 percentage points, depending on model specification.
\end{abstract}

\section{Acknowledgements}

I would like to thank Diderik Danbolt, Robert Durand, Paul Draper, Neil Garrod, Alan Gregory, Ian Hirst, Allan Hodgson (the editor), John Holland, Pinam Lampaphayom (the EFMA discussant), Robin Limmack, Bill Rees, Rob Watson, Pauline Weetman and two anonymous referees for helpful suggestions and comments, as well as the participants at the British Accounting Association Annual Conference in Birmingham 1997, the Irish Accounting and Finance Association Annual Conference in Dublin 1997 and the European Financial Management Association Annual Conference in Paris 1999 for comments on earlier versions of this paper. The responsibility for any remaining errors or omissions rests fully with the author. 


\section{CROSS-BORDER ACQUISITIONS INTO THE UK}

\section{- AN ANALYSIS OF TARGET COMPANY RETURNS}

\section{INTRODUCTION}

During the late 1980s, the UK witnessed a major takeover boom, fuelled to a large extent by cross-border acquisitions into the UK. In this paper, the extent to which shareholders of UK target companies gain from these cross-border acquisitions is analyzed and compared to the gains associated with domestic UK acquisitions. If capital markets and the market for corporate control are not segmented internationally, one would not expect the level of abnormal returns to target company shareholders to be systematically different in domestic and cross-border acquisitions (Fatemi and Furtado (1988), Franks and Harris (1991)). However, Kang (1993) argues that

"since the theory of FDI posits that imperfections ... give multinational firms a competitive advantage over local firms in the host country, cross-border acquisitions are likely to create more wealth than domestic acquisitions. Since targets tend to reap more of the benefits of the acquisitions, the theory suggests the wealth gains to targets of ... [foreign] firms are larger than those to targets ... [in domestic acquisitions]". (p. 348).

Despite the significant scale of cross-border acquisitions throughout the world, the empirical evidence with regard to cross-border acquisitions is still rather limited and heavily skewed towards the US market. While a number of studies (as discussed in the literature review below) have tested the differential wealth effects of domestic and cross-border acquisitions for target company shareholders in the US, no similar analysis of the target company cross-border effect has been undertaken for the UK. In this paper we address this important gap in the finance literature. We empirically investigate the validity of Kang's (1993) theoretical assertion for the UK by providing a comparative analysis of the gains to shareholders of UK companies targeted in domestic and cross-border acquisitions. Consistent with Kang's proposition - and the majority of the prior evidence for the US - we 
find target company shareholders in the UK to gain significantly more in cross-border than in domestic acquisitions. While this appears to be partly attributable to a payment effect, the target company cross-border effect remains highly significant, at somewhere between 6.02 and 9.17 percentage points (depending on model specification), once payment and other bid characteristics are controlled for. We also test various hypotheses as to why there might be a cross-border effect in the UK. We do not find support for either the EU market access hypothesis or an exchange rate effect. As there are several competing hypotheses for why a target company cross-border effect may exist and our empirical analysis is unable to distinguish between them, its precise cause remains a puzzle.

The paper is organized as follows. The factors identified in the literature as to why target company shareholders may expect to gain more in cross-border than in domestic acquisitions are discussed in section II. This is followed by a brief discussion in section III of prior empirical evidence on the target company cross-border effect. The data and methodology are explained in section IV. This section includes a discussion of several alternative hypotheses derived from the theoretical framework that may account for differential bid premia. These factors are controlled for and tested in the cross-sectional analysis, the results of which are presented in section V. Conclusions are provided in section VI.

\section{TARGET COMPANY CROSS-BORDER EFFECTS - THEORETICAL CONSIDERATIONS}

Factors suggested in the literature to explain why target shareholders may gain more in cross-border than in domestic acquisitions fall into four main categories: international risk diversification; market access; exchange rate effects; and managerial factors ${ }^{1}$

1. Domestic and cross-border acquisitions may produce different levels of abnormal returns if markets for corporate control are segmented across national boundaries (Fatemi and Furtado (1988)). The level of abnormal returns may also vary with the rules and regulations governing mergers and acquisitions or the efficiency of the market for corporate control (Conn and Connell (1990)). However, although these 
There is general agreement that shareholders benefit from international portfolio diversification (e.g., Solnik (1974) and Davis (1991)), but that in efficient security markets such benefits should not extend to corporate diversification (Sudia (1992), Markides and Ittner (1994), Hymer (1976), Jacquillat and Solnik (1978), Fatemi (1984), and Michel and Shaked (1986)). However, Hymer (1976), Hisey and Caves (1985) and Markides and Ittner (1994) argue that, under certain market inefficiencies, investors could benefit from international corporate diversification through cross-border acquisitions. For example, information asymmetries may mean that a company is better informed than its investors and thus able to make better investment decisions than its shareholders. Markides and Ittner add that "...the multinational corporation is performing a valuable service to investors in that it allows them to diversify their portfolios indirectly". (p. 346). Thus, it can be hypothesized that corporate international diversification has the potential of being beneficial to shareholders. If international diversification is an additional source of value to overseas bidders (and they are prepared to or forced by target company shareholders to pass on

factors may result in different levels of abnormal returns to target company shareholders in different countries, and to different levels of acquiror returns in domestic and cross-border acquisitions, the segmented or inefficient takeover markets hypotheses are unlikely to account for differential target company wealth effects in domestic and cross-border acquisitions within a country.

A further consideration relates to the scope for cost savings post acquisition. Jaquemin et al. (1989) find cross-border acquisitions within the EU to reveal little evidence to suggest that these transactions result in greater efficiencies or that economies of scale or monopoly powers are exploited. Indeed, economies of scale may be easier to achieve in domestic than in cross-border acquisitions. If acquiring companies share cost savings with target company shareholders, this would suggest that target company shareholders may gain more in domestic than in crossborder acquisitions. The effect of differential cost savings following domestic and cross-border acquisitions is not analysed in this study.

There is also a possibility that bidding companies based in some countries will be subject to more favorable tax treatment or accounting regulation than companies based in other countries. This may affect their ability or willingness to pay high takeover premia (Choi and Lee (1991)). Seventeen overseas countries are represented in the cross-border acquisitions into the UK covered in this study. An analysis of the different accounting regulations or tax treatments in these countries is beyond the scope of this paper. 
part of that benefit to them), one would expect target company shareholders to gain more in cross-border than in domestic acquisitions. We can therefore make the following prediction:

Hypothesis 1: Target company shareholders gain more in cross-border than in domestic acquisitions (International diversification benefit).

ii) Market Access

According to Pringle (1991), "FDI into industrial countries has always been dominated by ... [one] motive, i.e. market access." (p. 9). International takeovers may thus be motivated by a need to operate locally in order to avoid trade barriers. This appears to have been an important issue in the cross-border takeover activity in Europe following the passing of the Single European Act in 1985, with non-EU companies actively acquiring companies within the community before the introduction of the Single European Market in 1992 (Geroski and Vlassopoulos (1990) and Vasconcellos and Kish (1998)). If market access is valuable to foreign bidders, it may be anticipated that bidding companies from countries outside the EU are prepared to pay higher takeover premia than bidders based in the UK or other EU member countries.

Hypothesis 2a: Target company shareholders gain more in cross-border than in domestic acquisitions (UK market access).

Hypothesis 2b: In cross-border acquisitions into the UK, target company shareholders gain more in acquisitions by companies based outside the EU than in acquisitions by EU based bidders (EU market access).

iii) Exchange Rate Effects

Swenson (1993) and Vasconcellos and Kish (1998) note that the level of crossborder acquisitions into the US was higher at "...times when the U.S. dollar was relatively weak" (Swenson, p. 258). Froot and Stein (1991) argue that, due to information 
asymmetries, external financing is costly. Thus, the higher the wealth of the entrepreneur, the lower her cost of capital. If "...foreigners hold more of their wealth in nondollardenominated form, a depreciation of the dollar increases the relative wealth position of foreigners and hence lowers their relative cost of capital. This allows them to bid more aggressively for assets". (p. 1194). Exchange rate fluctuations might also have an impact on the level of abnormal returns to target company shareholders in cross-border acquisitions. Servaes and Zenner (1990), Harris and Ravenscraft (1991), Swenson (1993) and Kang (1993) all find US target company shareholders to gain more in cross-border acquisitions when the currency of the predator's home country is 'strong' relative to the target company's currency.

Harris and Ravenscraft (1991) "...measure the strength of the buyer's home currency relative to the U.S. dollar as the proportionate deviation from the average exchange rate for the sample period" (p. 832), while Swenson (1993) applies a dummy variable approach whereby the currency is classified as strong if, at the time of the bid, the exchange rate is above the average exchange rate for the sample period. Such approaches allow for an ex post classification of the strength of the currency, but suffer from a reliance on data unavailable at the time of the acquisition.

Not all studies find support for the exchange rate effect. For example, Cebenoyan et al. (1992), Feils (1993), and Dewenter (1995a) do not find the strength of the currency to have a significant impact on the level of abnormal returns. Morgan and Morgan (1990) argue that "when a currency fluctuates ... there are bound to be times at which it is undervalued, and these will provide bargain-hunting opportunities for overseas companies". (p. 66). However, Cakici et al. (1991) argue that "while a devalued dollar might enable the foreign buyer to acquire an American firm at a discount, the dollar cash flows subsequent to the merger are correspondingly less valuable when converted back into the foreign currency at the current exchange rate. Thus, a low foreign exchange value of the dollar does not justify high prices for American target firms". (p. 45). Similar arguments are put forward by Vasconcellos and Kish (1998). The theoretical issue of whether exchange rates 
have an impact on the level of abnormal returns to target company shareholders thus remains a controversial issue, and the empirical evidence is mixed. However, based on the majority of prior evidence, we make the following hypothesis:

Hypothesis 3: In cross-border acquisitions, target company abnormal returns are higher when Sterling is relatively weak against the currency of the overseas bidder. (Exchange rate benefit).

\section{iv) Managerial Factors}

As with domestic acquisitions, cross-border acquisitions may not only be driven by shareholder wealth maximization objectives, but may also be a result of agency conflict, with bidding company management aiming to maximize their own utility. Through acquisitions, management may increase their power, status, and salary. In an analysis of domestic UK acquisitions, Firth (1991) find acquiring company management to gain from mergers and acquisitions regardless of whether their shareholders gain or lose as a result of the transactions. If managers are pursuing power and status through empire building, cross-border acquisitions may be more advantageous to managers than domestic transactions.

In his hubris hypothesis, Roll (1986) argues that bidding companies tend to overestimate the value of synergies or other economic benefits of the merger. The target company bid premium may thus be the result of valuation error. If overseas companies are more difficult to value than domestic firms due to e.g., different accounting standards, valuation conventions, or the impact of exchange rate fluctuations on company value (Solnik (1996) and Shapiro (1999)), the size of any valuation error (and thus, the degree of any overpayment) may be larger in cross-border than in domestic acquisitions.

In an analysis of cross-border acquisitions into the UK, Danbolt (1995) finds that overseas bidding companies suffer significant negative abnormal returns, indicating that overseas bidders pay too high a price for their UK targets. Indeed, the post-bid performance of cross-border bidders appears to be significantly worse than the 
performance of domestic UK bidders (Danbolt (1996)). This suggests that any target company cross-border effect may be due to managerial overconfidence (consistent with Roll's (1986) hubris hypothesis) or managers of cross-border bidders pursuing the maximization of personal utility, rather than the maximization of shareholder wealth, to a greater extent than do domestic bidders.

Hypothesis 4: Target company shareholders gain more in cross-border than in domestic acquisitions (Managerial motives or hubris).

As can be seen from the above hypotheses, there are various competing theories as to why target company shareholders may gain more in cross-border than in domestic acquisitions. If there is a target company cross-border effect, it is difficult to ascertain why this is the case, given that several of the hypotheses $(1,2 \mathrm{a}$ and 4$)$ provide identical predictions. However, in section VI we test the EU market access hypothesis (2b) and the exchange rate effect hypothesis (3) in an attempt to ascertain whether these factors account for the target company cross-border effect.

\section{TARGET COMPANY CROSS-BORDER EFFECTS - PRIOR EMPIRICAL EVIDENCE}

The literature on domestic mergers and acquisitions in the UK (e.g., Franks and Harris (1989) and Limmack (1991)) as well as the evidence from other markets (such as e.g., Jensen and Ruback (1983) and Franks et al. (1991) for the US) invariably indicate that large abnormal returns accrue to target company shareholders. Although one would expect target company shareholders to gain significantly also in cross-border acquisitions, the level of such gains may, as explained in the previous section, be systematically different from those associated with domestic acquisitions.

For the US market, positive target company cross-border effects are found by e.g., Wansley et al. (1983), Tessema (1985), Harris and Ravenscraft (1991), Shaked et al. (1991), Cebenoyan et al. (1992), Marr et al. (1993), Swenson (1993), and Cheng and Chan 
(1995), although Dewenter (1995a) does not find the abnormal returns to US target company shareholders to be systematically different in domestic and cross-border acquisitions.

With regard to the UK market, it appears that only two previous studies have analyzed the wealth effects to target company shareholders from cross-border acquisitions into the $\mathrm{UK}^{2}$. However, neither of these articles analyze the differential wealth effects to target company shareholders associated with domestic and cross-border acquisitions (i.e., target company cross-border effects). Conn and Connell (1990) analyze the abnormal returns of both bidding and target companies in cross-border mergers between US and UK companies during the 1971 to 1980 period. Over a ten month period leading up to and including the bid month, the market model non-logarithmic cumulative abnormal returns (CAR) to UK targets amount to $18 \%$. The level of CAR to UK target company shareholders is, according to Conn and Connell, low not only in comparison to the gains to US targets ( $40 \%$ over the same time period), but also low in comparison to what is generally found in studies of domestic acquisitions in the UK.

A similar study to that of Conn and Connell (1990) is that of Feils (1993), who analyze target and bidding companies in cross-border acquisitions between the UK and the US, as well as German acquisitions of US firms during the time period 1980 to 1990 . Using the market model for an 11-day event window ( $\forall 5$ days relative to the day of the bid announcement), she concludes that UK target company shareholders gain significantly less (cumulative log abnormal returns of $16.33 \%$ ) than do US target company shareholders (25.52\%) in cross-border acquisitions between the two markets. As with Conn and Connell (1990), Feils does not analyze UK target companies in domestic acquisitions, and is thus unable to comment upon the nature of any target company cross-border effects in the UK.

Prior studies tend to find US target company shareholders to gain more in crossborder than in domestic acquisitions. However, the low level of abnormal returns to target

2. Connell and Conn (1993) also discuss cross-border acquisitions. This is, however, predominately a methodological paper, and use the same data as in Conn and Connell (1990). 
company shareholders in cross-border acquisitions into the UK (as reported by Conn and Connell (1990) and Feils (1993)), may suggest that the presence of a similar target company cross-border effect in the UK is unlikely. In this paper we explicitly test whether the level of abnormal returns to shareholders in listed UK companies targeted in crossborder and domestic acquisitions are systematically different.

\section{DATA SOURCES AND METHODOLOGY}

This paper contains an analysis of 116 cross-border and 510 domestic takeover bids for listed UK companies made on or after 1 January 1986 and for which the bid outcome was known prior to the end of December $1991^{3}$. Information as to what takeover bids took place, the name of the bidding and target companies, the nationality of the bidder, the bid outcome, whether or not the bid was competitive, or revised, the form of payment offered, and the percentage stake by the bidding company in the target at the time of the bid

3. These sample sizes refer to those for the index model. Due to their more stringent data requirements, the sample sizes for the other test models are somewhat lower, as specified in the tables. During the six year period of analysis, 756 domestic and 208 cross-border takeover bids were announced. However, as the analysis is based on ordinary shares, 3 domestic bids for preference shares are excluded from the analysis. In addition, partial takeover bids ( 5 cross-border and 8 domestic) are excluded, as these bids require special dispensation from the Takeover Code (The Panel on Takeovers and Mergers (1990)); as is common in event studies (e.g., Dimson and Fraletti (1986), bids for investment trusts (9 cross-border and 43 domestic) are excluded due to different valuation issues relating to such companies; bids for water companies (13 cross-border and 6 domestic) are excluded as such bids are strictly regulated through the Water Act 1989 (DTI (1991); bids where two or more companies jointly bid for the target (2 cross-border and 9 domestic) are excluded, as are ( 1 cross-border and 3 domestic) follow-on bids by the same bidder for the same target within a twelve month period. In competitive bids, bids by unsuccessful bidders (or the second and subsequent bidders where no bidder was successful) are excluded from the analysis (17 cross-border and 38 domestic). In addition, competitive bids involving both domestic and cross-border bidders are also excluded ( 7 cross-border and 10 domestic), as these transactions do not allow for a clear analysis of any target company cross-border effect. Finally, bids where the Acquisitions Monthly listing (4 cross-border and 15 domestic) is incomplete is excluded from the analysis. Following this screening process, 150 cross-border and 621 domestic bids remain. Lack of return data further reduce the sample to 119 cross-border and 520 domestic takeover bids. The abnormal returns (CAR from $t-2$ to $t+1$ ) are more than 3 standard deviations away from the mean (with at least 2 of the 5 test models) for 3 cross-border and 10 domestic bids. These outliers are removed. 
announcement (the toehold), is obtained from Acquisitions Monthly, while exchange rate data is obtained from Datastream. Market capitalizations of equity are obtained from the London Business School Risk Measurement Service (edited by Dimson and Marsh) ${ }^{4}$, while monthly log returns are obtained from the London Business School Share Price Database.

For the majority of the bidding companies, we adopt the classification of nationality used by Acquisitions Monthly (which classifies the bidding companies according to where they, or their parent companies if the bidding company is a subsidiary, have their registered office). However, where the bidding company is not listed in its home market but listed elsewhere, the nationality of the bidder is reclassified to the country of the main stock market listing of the company ${ }^{5}$.

The analysis is based on event-study methodology (Fama et al. (1969)), where the abnormal return on share $i$ is defined as:

$$
A R_{i}=R_{i}-E\left(R_{i}\right)
$$

where $A R_{i}$ refers to the abnormal return, $R_{i}$ to the observed return, and $E\left(R_{i}\right)$ to the return one would have expected on share $i$ had no takeover bid been announced.

However, controversy surrounds the specification of the appropriate benchmark model for estimating the expected return. While the market model is probably the most commonly applied model in the analysis of mergers and acquisitions, researchers such as Connell and Conn (1993) and Gregory (1997) suggest that this model has certain limitations, particularly regarding the assumption of stationary $\alpha$ and $\beta$ values. In addition, while simulation studies suggest that abnormal returns are relatively insensitive to the detailed model specification (e.g., Brown and Warner $(1980,1985)$ ), several empirical studies find the results to vary significantly depending on the model applied (e.g., Franks

4. Market values are obtained from the quarterly issue published 6 to 9 month prior to the bid announcement, in order to ensure that the values are not influenced by rumours regarding the forthcoming bid announcement.

5. The nationalities of the bidding companies in the 116 cross-border acquisitions are: Australia (11), Belgium (1), Canada (2), Eire (4), Finland (1), France (16), Germany (8), Hong Kong (1), Japan (6), Liechtenstein (3), Netherlands (6), New Zealand (9), South Africa (2), Saudi Arabia (1), Sweden (12), Switzerland (10), and US (23). 
and Harris (1989) and Danbolt $(1995,1996))$. It is therefore common to apply several models ${ }^{6}$ to test the robustness of the findings.

In this study we use five different test models. Firstly, following Franks and Harris (1989), we apply the market model (MM), the capital asset pricing model (CAPM) and the index model (IM). Using these commonly adopted models allow for a comparison of the results in this study to those obtained in other studies using these models. However, as argued by Gregory (1997), “...a 'good’ benchmark must control for the size effect”. (p. 998). Indeed, controlling for the commonly observed size effect (Banz (1981), Reinganum (1981), Keim (1983), and Blume and Stambaug (1983)) in the return generating process may be of particular importance in studies of mergers and acquisitions, as target companies tend to be small (Kennedy and Limmack (1996), Gregory (1997) and Higson and Elliott (1998)).

In this paper, two such size-adjusted benchmarks are applied in addition to the three more conventional models. The size-deciles (SD) control model compare the return on the share to a benchmark derived from a portfolio of companies with similar market capitalization to the company in question. The size deciles are constructed using monthly log return data for all UK companies available from Datastream during each month. Target companies are matched with the appropriate size decile returns based on the pre-bid market value of the target. The Hoare-Govett small companies model is a variant of the capital asset pricing model including both the overall market index and a stock market index for small capitalization companies in the benchmark. The Hoare-Govett smaller companies index is a value-weighted index of the bottom $80 \%$ of UK companies by market capitalization. The HGSC model is discussed further in Gregory (1997), who finds the

6. For example, Danbolt (1995) and Sudarsanam et al. (1996) apply two control models (Danbolt use the market model (MM) and the index model (IM), while Sudarsanam et al. use the IM and a version of MM with Dimson (1979) thin-trading adjusted betas), Franks and Harris (1989) and Danbolt (1996) apply three models (the MM, the IM and the capital asset pricing model (CAPM)), while Gregory (1997) apply six different control models (CAPM, the Dimson and Marsh (1986) risk and size adjusted model (DM), a multi-index model based on smaller deciles minus larger deciles returns (SML), a multi-index model based on the Hoare Govett smaller companies index (HGSC), and the Fama and French (1996) three factor model 
model to capture abnormal returns well. The models applied in this study are specified as follows:

$$
\begin{array}{ll}
\text { IM: } & \mathrm{R}_{\mathrm{i}}=\mathrm{R}_{\mathrm{m}}+\mu_{\mathrm{i}} \\
\text { MM: } & \mathrm{R}_{\mathrm{i}}=\alpha_{\mathrm{i}}+\beta_{\mathrm{i}} \mathrm{R}_{\mathrm{m}}+\mu_{\mathrm{i}} \\
\text { CAPM: } & \mathrm{R}_{\mathrm{i}}=\mathrm{R}_{\mathrm{f}}+\beta_{\mathrm{i}}\left(\mathrm{R}_{\mathrm{m}}-\mathrm{R}_{\mathrm{f}}\right)+\mu_{\mathrm{i}} \\
\text { HGSC: } & \mathrm{R}_{\mathrm{i}}=\mathrm{R}_{\mathrm{f}}+\beta_{1 i}\left(\mathrm{R}_{\mathrm{m}}-\mathrm{R}_{\mathrm{f}}\right)+\beta_{2 \mathrm{i}}\left(\mathrm{R}_{\mathrm{HG}}-\mathrm{R}_{\mathrm{m}}\right)+\mu_{\mathrm{i}} \\
\text { SD: } & \mathrm{R}_{\mathrm{i}}=\mathrm{R}_{\mathrm{SD}}+\mu_{\mathrm{i}}
\end{array}
$$

where $R_{i}$ refers to the return on the share (calculated as $\log _{e}\left[\left(P_{i t}+D_{i t}\right) / P_{i t-1}\right]$, with $P_{i t}$ referring to the share price at time period t and $D$ to dividends), $R_{f}$ the risk-free interest rate, $R_{m}$ the return on the Financial Times Actuaries index for the UK market, $\alpha_{i}$ and $\beta_{i}$ regression coefficients, $R_{H G}$ the return on the Hoare Govett small companies index, $R_{S D}$ the equally weighted return on the deciles portfolio of companies with similar market values to the company being analyzed, and $\mu_{\mathrm{i}}$ the error term (the estimated abnormal return during the analysis period). Time periods refer to months relative to the month of the bid announcement, which is denoted t. The MM, CAPM and HGSC parameters are estimated on a minimum of 30 observations during the period from t-68 to t-9.

This study adopts a fairly long analysis period, stretching from month t-8 to t+5. Previous literature (e.g., Franks et al. (1977) and Limmack (1991)) find target company share prices to rise several months prior to bid announcement. Adopting a long pre-bid analysis period allows us to establish whether the pattern of share price performance leading up to the bid differs between domestic and cross-border acquisitions, and to analyze whether the pre-bid performance of target companies differs depending on whether the bidding company is based in the UK or abroad.

The inclusion of the post-bid period allows the capture of later price reactions in the context of the UK merger timetable regulation which may allow the bid process to extend over several months ${ }^{7}$. Post-bid data thus allows for an analysis of the impact of (FF3F)).

7. For a discussion of UK merger regulation, see Sudarsanam (1995). 
competitive bids, bid revision, and bid outcome.

The level of statistical significance of the equally weighted abnormal and cumulative abnormal returns in domestic and cross-border acquisitions, is tested using the crosssectional t-test (Strong (1992)). Following Strong (1992), the Patell Standardized Residual (PSR) Test (Patell (1976)) is applied for the market model. The PSR z-scores and MM tstatistics are generally very similar. The differences in abnormal returns in cross-border and domestic acquisitions is tested using a two-sample difference in mean t-test (Weiss and Hassett (1986)). The level of statistical significance is also tested using the Wilcoxon signed-rank nonparametric test of the median. The level of statistical significance using nonparametric statistics is generally similar to those using the t-test, and overall provide consistent conclusions to those drawn based on the parametric statistics ${ }^{8}$.

Previous studies have identified a number of acquisition characteristics which influence the level of target company abnormal returns. It is possible that any cross-border effect simply reflect the different characteristics of companies targeted by domestic and foreign bidders or the nature of the bid (Lessard (1993)). These characteristics are discussed below and subsequently introduced into the returns models to control for their influence. Summary statistics for the cross-sectional variables included in this study are given in Table 1.

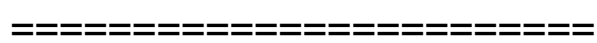

Table 1 about here

(i) Payment. In cash-only acquisitions, target company shareholders become immediately liable for capital gains tax (CGT) on any inflation-adjusted capital gain above the annual tax-free threshold, while if the payment is in loan stock, the CGT becomes payable when the loan is repaid (or the loan stock disposed of). In equity bids, no CGT would usually be payable at the time of the acquisition, but rather

8. Notes to the tables highlight cases where parametric and nonparametric statistics provide inconclusive results as to the significance of the coefficients. 
when the new shares in the bidding company are disposed of ${ }^{9}$. Consequently, in order to compensate for the tax effect, it can be hypothesized that target company shareholders demand a higher takeover premium in cash than in equity offers (Davidson and Cheng (1997)). Indeed, prior studies such as Wansley et al. (1983), Huang and Walkling (1987), Franks et al. (1988), Harris and Ravenscraft (1991) and Sudarsanam et al. (1996) do find that target company shareholders gain more in cash financed than in equity offers. Due to the tax advantages of loan note alternatives over cash payments, one can also hypothesize that target shareholders will settle for lower premia in cash offers with full cash alternatives.

However, Davidson and Cheng (1997) argue that "[t]here are two explanations for the observed difference in abnormal returns between the payment methods. [In addition to tax considerations]... cash bids reduce the asymmetric information problem that would be created in an exchange of common stock" ( $p$. 465). Travlos (1987), Wansley et al. (1987), Franks et al. (1988), Servaes (1991) and Aggrawal et al. (1992) all find bidding company shareholders to experience negative abnormal returns following equity financed acquisitions ${ }^{10}$. If target company shareholders receive payment in the form of shares in the bidder, these negative abnormal returns may result in low abnormal returns to target company shareholders. Target shareholders can therefore be expected to gain more in cash than in equity offers. A cash alternative to the equity offer should alleviate some of the information problems, thus resulting in higher abnormal returns to target company shareholders.

The payment effect is analyzed by evaluating the impact of the composition

9. For a discussion of the tax implications of the method of payment in UK acquisitions, see Sudarsanam (1995).

10. Factors affecting the decision as to what form of payment to offer include not only tax considerations and information effects. As discussed in Martin (1996), other aspects affecting the payment decision include managerial ownership and control issues, pre-bid share performance, cash balances, the importance of institutional shareholders and block holders, and the presence of growth opportunities. 
of the offer. The analysis is based on five categories of cash only, cash with full loan note alternative, equity only, equity with full cash alternative, and all other hybrid forms of payment grouped together in the fifth category. Given that a significantly higher proportion of cross-border than domestic acquisitions are cash offers, a payment effect, if present, may account for part of the observed crossborder effect. Based on theoretical predictions and the majority of the prior evidence, we make the following hypotheses:

Hypothesis 5a: Target company shareholders gain more in cash than in equity offers (tax effects and/or information asymmetries).

Hypothesis 5b: Target company shareholders gain less in cash offers with loan note alternatives than in pure cash offers (tax effects).

Hypothesis 5c: Target company shareholders gain more in equity offers with cash alternative than in pure equity offers (information asymmetries).

(ii) Competitive bids. Studies such as Michel and Shaked (1986), Stulz et al. (1990), Kaplan and Weisbach (1992) and De et al. (1996) for domestic US acquisitions, and Song (1993) and Swenson (1993) for cross-border acquisitions, find US targets to gain substantially more in competitive than in single bidder takeovers contests. Dewenter (1995a\&b) finds target company shareholders to gain marginally more in competitive bids, although not significantly so. In the UK market, Sudarsanam et al. (1996) find, rather surprisingly, target company shareholders to gain marginally less where there are multiple bids. However, all extant research points to a competition effect and so a dummy is introduced into the model (where 1=competitive and 0 otherwise). A significantly higher proportion of domestic than cross-border bids are competitive. If the effect of bid competition is to increase the offer price, this would suggest that domestic rather than cross-border acquisitions should ceteris paribus produce the higher abnormal returns.

Hypothesis 6: Target company shareholders gain more in competitive bids than 
when only one company bids for the target firm.

(iii) Bid revision. Franks and Harris (1989) find UK target company shareholders to gain significantly more in revised bids, although Limmack (1991) for UK acquisitions and De et al. (1996) for the US find bid revision to have relatively little impact on the level of abnormal returns to target company shareholders. A bid revision invariably means an improvement in the terms of the offer, either by increasing the value of the offer or by adding choice with regard to the form of payment. Again a dummy is introduced into the model (where 1=revised and 0 otherwise) to control for this potential factor in the target company premium. However, as the same proportion of domestic and cross-border offers are revised, bid revision is unlikely to account for the observed cross-border effect.

Hypothesis 7: Target company shareholders gain more when the bidder revise the terms of the offer.

(iv) Outcome. In their review paper of domestic US acquisitions, Jensen and Ruback (1983) observe that although the level of abnormal returns to target company shareholders in failed acquisitions is at least as high as that of successful acquisitions at the time of the bid, target company shareholders experience negative abnormal returns on the announcement of the unsuccessful bid outcome. A dummy variable (where $1=$ failed and $0=$ success) indicates the result of the bid. While a slightly higher proportion of domestic than cross-border offers fail, the difference is not statistically significant.

Hypothesis 8: Target company shareholders gain more in successful than in failed acquisitions.

(v) Bid toehold. The prior evidence with regard to the effect of bidder toehold on target company returns is rather mixed. Sudarsanam et al. (1996) find pre-bid toeholds to 
have a significant negative impact on the level of abnormal returns to UK target company shareholders, although Franks and Harris (1989) find UK target company shareholders to gain more when the bidding company hold a large stake (in excess of $30 \%$ ) prior to the bid announcement. However, as bidding companies with large pre-bid stakes require proportionately fewer acceptances at the time of the bid in order to obtain control, it is hypothesized that the abnormal returns to target company shareholders is inversely related to the proportion of target company shares held by the bidding company prior to the acquisition. Given that pre-bid stakes tend to be significantly higher in cross-border than in domestic acquisitions, this would suggest ceteris paribus that domestic rather than cross-border acquisitions should offer the higher abnormal returns. The percentage holding in the target by the bidder at the time of the bid announcement is used as the control variable here.

Hypothesis 9: Target company shareholders gain less the higher the percentage of target company shares owned by the acquiring company prior to the takeover bid.

(vi) Size. As discussed above, the size effect may cause the observed company return to be a function of the market value of the company. In acquisitions, it is also possible that bidding companies can afford to be comparatively more generous with small targets, thus paying a higher premium to small than to larger target companies. Indeed, Peterson and Peterson (1991) argue that "...smaller [US] target firms receive greater absolute returns...". (p. 401). Consequently, in addition to applying size-adjusted models, a size variable (the log of the pre-bid market value) is included in the cross-sectional analysis in order to analyze whether target company abnormal returns are dependent on the size of the company ${ }^{11}$. While

11. Another variable which has in the literature been found to be of some importance, is the relative size of the target and bidding companies. For the UK, Sudarsanam et al. (1996) find target company shareholders to gain more when their company is 
target companies tend to be somewhat larger in cross-border than in domestic acquisitions, the difference in average size is not statistically significant.

Hypothesis 10: The level of abnormal returns to target company shareholders is inversely related to the size of the target company.

As a benchmark for the analysis of the cross-border effect, we first test the validity of hypotheses 5 to 10 for the sample of domestic target companies. We run cross-sectional OLS regressions of the target company cumulative abnormal returns over the period t- 2 to $\mathrm{t}+1$ months against the cross-sectional variables. The regression equation is specified as follows:

$$
\begin{aligned}
\text { CARi }_{-2,+1}= & \alpha+\beta_{1} \text { Competitive }+\beta_{2} \text { Revised }+\beta_{3} \text { Outcome } \\
& +\beta_{4} \text { Stake } \%+\beta_{5} \text { LogMV }+\beta_{6} \text { Cash }+\beta_{7} \text { Cash w/ln } \\
& +\beta_{8} \text { Equity }+\beta_{9} \text { Equity w/cash }+\mu
\end{aligned}
$$

where $\mathrm{CARi}_{-2,+1}$ is the cumulative abnormal return on share $i$ over the four month period from two months prior to one month after the month of the bid announcement; $\alpha$ the constant term; $\beta$ the slope coefficients; Competitive a dummy variable taking the value 1 if the bid was competitive; Revised a dummy variable taking the value 1 if the offer was revised; Outcome a dummy variable taking the value 1 if the bid failed; Stake\% the percentage stake in the target company by the bidding company prior to the bid announcement; LogMV the natural logarithm of the pre-bid market capitalization of the target company; Cash a dummy variable taking the value 1 for cash-only bids; Cash w/ln a dummy variable taking the value 1 if the payment offered was cash with a full loan note alternative; Equity a dummy variable taking the value 1 if shares in the acquiring company was the only form of payment offered; Equity w/cash a dummy variable taking the value 1 if

small relative to the size of the bidder. However, in this study, data on the market value of the bidding company is missing for 257 target companies. Inclusion of the relative size variable thus significantly reduces sample sizes. The variable was included in the cross-sectional regressions, but the regression coefficient for relative size was found to be virtually zero and statistically insignificant. The regressions reported thus exclude this variable. 
the method of payment offered was equity with a full cash alternative; and $\mu$ the error term.

We next test whether the target company cross-border effect is attributable to the differences in the characteristics of domestic and cross-border acquisitions. We regress the cumulative abnormal returns for the whole sample of domestic and cross-border acquisitions on the same cross-sectional variables as in equation 7 , but add a dummy variable taking the value 1 in cross-border acquisitions. The regression equation thus becomes:

$$
\begin{aligned}
\text { CARi }_{-2,+1}= & \alpha+\beta_{1} \text { Competitive }+\beta_{2} \text { Revised }+\beta_{3} \text { Outcome } \\
& +\beta_{4} \text { Stake } \%+\beta_{5} \text { LogMV }+\beta_{6} \text { Cash }+\beta_{7} \text { Cash w/ln } \\
& +\beta_{8} \text { Equity }+\beta_{9} \text { Equity w/cash }+\pi_{1-4} \text { Cross-Border }+\mu
\end{aligned}
$$

A significant coefficient for $\pi_{1-4}$ would indicate that the target company cross-border effect remains once we control for the bid specific characteristics.

$\pi_{1-4}$ in equation 8 in effect provides a joint test of hypotheses 1 to 4 , all of which predict that target company shareholders will gain more in cross-border than in domestic acquisitions. In a further cross-sectional regression, this time on the sub-sample of crossborder targets, we explicitly test two of these hypotheses. In particular, we test whether target shareholders gain more in cross-border acquisitions by companies based outside the EU than in other cross-border acquisitions (the EU market access hypothesis, as specified in hypothesis $2 b$ ), and whether the abnormal returns are related to the relative strength or Sterling and the currency of the overseas acquiring company (the exchange rate benefit hypothesis, as specified in hypothesis 3). The regression equation is specified as follows:

$$
\begin{aligned}
\text { CARi }_{-2,+1}= & \alpha+\beta_{1} \text { Competitive }+\beta_{2} \text { Revised }+\beta_{3} \text { Outcome } \\
& +\beta_{4} \text { Stake } \%+\beta_{5} \text { LogMV }+\beta_{6} \text { Cash }+\beta_{7} \text { Cash w/ln } \\
& +\beta_{8} \text { Equity }+\beta_{9} \text { Equity w/cash }+\pi_{2 \mathrm{~b}-1} \text { Non-EU European } \\
& +\pi_{2 \mathrm{~b}-2} \text { US }+\pi_{2 \mathrm{~b}-3} \text { Rest of World }+\pi_{3} \text { Exchange Rate }+\mu
\end{aligned}
$$

where Non-EU Europe is a dummy variable taking the value 1 in cross-border acquisitions by companies based in European countries which were not members of the European Union at the time of the bid announcement; US a dummy taking the value 1 in acquisitions 
by US companies; and Rest of World a dummy variable taking the value 1 in cross-border acquisitions by companies located outside of Europe or the US. Cross-border acquisitions by companies based in other EU member states are captured by the intercept.

The Exchange Rate variable measures the deviation in the exchange rate between Sterling and the home currency of the overseas acquiring company during the month of the bid announcement from the mean exchange rate during the previous two years. This definition of the exchange rate variable uses only information available to the bidder at the time of the bid, therefore avoiding the problem of hindsight present in the exchange rate variables applied by e.g., Harris and Ravenscraft (1991) and Svenson (1993).

Significant positive coefficients for $\pi_{2 \mathrm{~b}-1}, \pi_{2 \mathrm{~b}-2}$, and $\pi_{2 \mathrm{~b}-3}$ would indicate support for hypothesis $2 \mathrm{~b}$, while a significant positive coefficient for $\pi_{3}$ would indicate support for hypothesis 3.

Multicollinearity problems may occur if the independent variables are highly correlated. The correlation matrix reported in the appendix indicate that multicollinearity is unlikely to affect the regression coefficients in this analysis. While some of the correlation coefficients are statistically significant, the coefficients are generally small. However, in order to test the robustness of our results, we analyze the effect of multicollinearity by means of the variance inflation factors (VIF) (Montgomery and Peck (1982)). The variance inflation factor for each regression coefficient $x_{j}$ is calculated as:

$$
\mathrm{VIF}_{j}=1 /\left(1-\mathrm{R}_{j}^{2}\right)
$$

where $\mathrm{R}_{j}^{2}$ is the multiple correlation coefficient of $x_{j}$ regressed on the remaining explanatory variable (Belsley et al. (1980)). As argued by Chatterjee and Price (1991), "values of variance inflation factors greater than 10 is often taken as a signal that the data have collinearity problems". (p. 191). While the maximum VIF coefficient in our analysis is 4.3, the vast majority of the VIF scores are below 1.5. Our cross sectional regression results are therefore not adversely affected by multicollinearity.

Similarly, we test that our results are not driven by heteroskedasticity using the Park test (Park (1966), Gujarati (1988)), where the square of the regression residuals are 
regressed against the independent variables. For example, the Park test of the crosssectional regression for domestic targets (equation 7 above) is specified as follows:

$$
\begin{aligned}
\mu^{2}= & \alpha+\beta_{1} \text { Competitive }+\beta_{2} \text { Revised }+\beta_{3} \text { Outcome } \\
& +\beta_{4} \text { Stake } \%+\beta_{5} \text { LogMV }+\beta_{6} \text { Cash }+\beta_{7} \text { Cash w/ln } \\
& +\beta_{8} \text { Equity }+\beta_{9} \text { Equity w/cash }+,
\end{aligned}
$$

where $\mu^{2}$ refers to the squared residuals from the regression analysis using equation 7 . As can be seen from tables 5 to 7, none of the Park test regressions are significant. We can therefore conclude that there is no heteriskediasticity in the error variance.

As a further robustness check, all the cross-sectional regressions are run using robust (rank) regressions in addition to the OLS. The results from these regressions are very similar to those obtained using OLS (both in terms of the levels of the coefficients and their significance levels), indicating that our results are not affected by our assumption of normally distributed abnormal returns ${ }^{12}$.

\section{ANALYSIS OF RESULTS}

Target Company Shareholders in Domestic Acquisitions

The average abnormal returns to the listed UK companies targeted in domestic acquisitions during the 1986-1991 period, are detailed in Table 2. As can be clearly seen from this table, target companies in domestic acquisitions substantially under perform during the pre-bid period, with all models indicating negative abnormal returns in every month from t-8 to t-3. It is inappropriate to directly attribute these large negative abnormal returns during the pre-bid period to the forthcoming bid announcements. A more plausible explanation is that bidding companies target companies with at least a short-term history of poor share price performance. The abnormal returns turn positive in month $\mathrm{t}-2$, and during t-1 and t significant positive abnormal returns accrue to target company shareholders in domestic UK acquisitions. The abnormal returns during the month of the bid

12. Notes to the tables highlight cases where parametric and nonparametric statistics provide inconclusive results as to the significance of the coefficients. 
announcement amount to a highly significant $18.35 \%$ to $20.13 \%$, depending on the test model applied. Targets tend to encounter negative abnormal returns during the months following the bid announcement, although these are mostly relatively small.

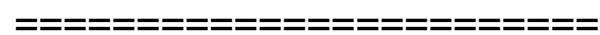

Table 2 about here

Target Company Shareholders in Cross-Border Acquisitions

The average abnormal returns to UK target companies in cross-border acquisitions into the UK are given in Table 3. As is the case with target companies in domestic acquisitions, cross-border targets also, on average, under perform during the period from t8 to t-3. However, unlike what is the case for domestic targets, the abnormal returns are significantly positive as early as two months prior to the bid announcement. These results indicate that cross-border acquisitions tend to be anticipated by the market earlier than are domestic acquisitions. These large pre-bid abnormal returns in cross-border acquisitions highlight the potential limitation of several previous studies such as Tessema (1985), Feils (1993), and Eun et al. (1995) which apply short event windows to the analysis of abnormal returns to target companies in cross-border acquisitions.

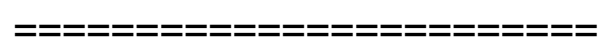

Table 3 about here

During the month of the bid announcement, the average abnormal return amounts to somewhere between $19.21 \%$ and $21.38 \%$ (depending on the test model applied), and is highly significant with all models. Significant positive abnormal returns are also observed for the month following the initial bid announcement ${ }^{13}$. This may be due to bid revision or

13. During the post-bid period, a large proportion of target companies are no longer listed. When share returns are missing, the abnormal return has been assumed to be zero. While the mean abnormal return is significant during some of the post-bid periods, the large number of zeros cause the medians to be indistinguishable from 
the bid turning competitive. The effect of these and other bid characteristics on the level of abnormal returns is analyzed in the cross-sectional analysis.

\section{Target Company Cross-Border Effects}

The differences in average abnormal returns to shareholders in the 116 cross-border and the 510 domestic acquisitions, are given in Table 4. As discussed above, UK target companies in both cross-border and domestic acquisitions significantly under perform over the period from 8 to 3 months prior to the month of the bid announcement. The differences in abnormal returns during these pre-bid months are generally small and not statistically significant.

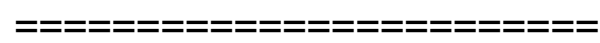

Table 4 about here

During the month of the bid announcement, there appears to be no significant crossborder effect. However, UK targets in cross-border acquisitions gain more than target company shareholders in domestic transactions during the two months leading up to the bid, as well as the month after the bid announcement. A positive, although fairly small, cross-border effect is also observed for month $\mathrm{t}+2$.

The appropriate event window for analyzing the effect on shareholder returns of mergers and acquisitions is controversial. While long windows may introduce noise, short windows are unlikely to capture the full effect of the transaction if there is bid leakage or if price sensitive information is released after the initial bid announcement, such as the announcement of bid outcome, bid revision, or the entry of other companies in the bidding contest. However, in this paper, where the focus is on the difference in the level of abnormal returns to target company shareholders in domestic and cross-border acquisitions (i.e., the target company cross-border effect), a fairly agnostic view can be taken with regard to what event window is the most appropriate. From Table 4, it can be

zero. 
seen that the cross-border effect appears to be most prominent during the time period from $\mathrm{t}-2$ to $\mathrm{t}+1$. Cumulating the abnormal returns over these four months produce a cumulative cross-border effect of somewhere between $5.99 \%$ and $11.03 \%$, statistically significant with all test models. The main aim of the cross-sectional analysis is to establish whether the cross-border effect is attributable to the different characteristics of domestic and crossborder takeover bids, and to test our hypotheses as to why a target company cross-border effect may exist. Consequently, we base this analysis on the cumulative abnormal returns from $\mathrm{t}-2$ to $t+1$, although it is acknowledged that this event window (ending one month after the month of the bid announcement) is unlikely to capture the full effect of bid outcome, bid revision or competitive bids ${ }^{14}$.

\section{Cross-Sectional Analysis of Abnormal Returns in Domestic Acquisitions}

We first test the significance of these bid specific variables for our sample of domestic acquisitions. The regression output from the cross-sectional analysis is reported in Table 5. During the four month period from $\mathrm{t}-2$ to $\mathrm{t}+1$, target company shareholders gain significantly more in competitive bids ${ }^{15}$. This is consistent with the majority of prior US evidence, although contrary to Sudarsanam et al.'s (1996) finding for the UK. Shareholders of domestic target companies are also found to gain more in revised bids, while the level of abnormal returns is lower for targets in failed bids. We thus find support for hypotheses 6 and 7, and some support for hypothesis 8.

14. The overall results in this study are robust to the specification of the event window. With a longer event window from $t-2$ to $t+5$, the coefficients for competitive and revised bids are significantly positive, while bid outcome and log MV are significantly negative. However, the main conclusions remain unaltered, with the dummy for the cross-border effect (see Table 6) being marginally larger (ranging from 6.22 to 9.72 percentage points depending on the test model applied) for the longer event-window.

15. This study covers a time period with relatively large numbers of competitive bids, and the proportion of domestic bids turning competitive in this study (13.6\%) exceed what is found in previous UK studies. For example, Franks and Harris (1989) find $6 \%$ of their targets to be subject to competitive bids, while Sudarsanam et al. (1996) find competitive bids to account for $8 \%$ of their sample. 
Table 5 about here

Due to the limited sample sizes for some of the payment categories, only four of the different methods of payment offered can be explicitly tested for in the cross-sectional analysis (with the remaining bids being captured by the constant term) ${ }^{16}$. Target shareholders are found to gain significantly less in equity-only than in other bids. This is consistent with prior research (e.g., Franks et al (1988) and Harris and Ravenscraft (1991)). Cash-only bids also appear to be ill received by the market. This may be due to the tax implications of such offers, with target shareholders preferring cash offers with loan note alternatives, due to their more favorable tax treatment (Sudarsanam (1995)). The results seem to suggest that the cash-only bids are not sufficiently high (relative to the other types of bids) to fully compensate for the adverse tax treatment of such offers. The results thus support hypothesis $5 \mathrm{a}$, but contradict hypotheses $5 \mathrm{~b}$ and $\mathrm{c}$.

We find the pre-bid stake of the bidder to have negligible impact on target company abnormal returns. There is thus no support for hypothesis 9 . However, consistent with hypothesis 10 , we find shareholders in small companies to gain more (in percentage terms) than do shareholders in larger companies, suggesting that bidding companies are relatively more generous in their acquisitions of small targets.

\section{Cross-Sectional Analysis of the Cross-Border Effect}

In the previous section we established that bid specific variables explain a significant proportion of the cross-sectional variation in target company abnormal returns. In order to test whether these bid characteristics account for the target company cross-border effect, we repeat the cross-sectional analysis for the whole sample of cross-border and domestic

16. The methods of payment offered in the domestic acquisitions in this study are broadly similar to that observed by Sudarsanam et al. (1996) in their study of acquisitions in the UK. In their sample, $16 \%$ of the transactions are all-cash (compared to $13 \%$ in this study), 17\% (19\%) all-equity, and 67\% (70\%) mixed-pay offers. 
acquisitions, with a cross-border dummy added to the explanatory variables.

As can be seen from Table 6, the impact of bid competition is marginally larger for the whole sample than for domestic targets separately (as reported in Table 5). Target company shareholders, on average, encounter an additional abnormal return of approximately 9 to 13 percentage points in competitive bids, and 4 to 6 percentage points in revised bids. There is thus strong support for hypotheses 6 and 7.

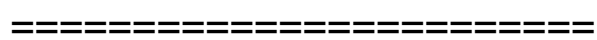

Table 6 about here

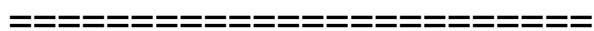

The coefficient for company size is negative, indicating that smaller target companies receive larger percentage abnormal returns than do larger targets, consistent with hypothesis 10 . However, the impact of company size is not statistically significant with the size deciles model, indicating that the positive size coefficient may, at least in part, be attributable to the stock market size anomaly, rather than solely being due to bidders being comparatively generous with small target companies.

The method of payment appears to have a significant impact on target company returns, with cash-only and, in particular, equity-only bids resulting in low abnormal returns. There is thus support for hypothesis $5 \mathrm{a}$, but not for $5 \mathrm{~b}$. However, while bid specific variables explain a significant proportion of the cross-sectional variation in target company abnormal returns, these variables do not appear to account for the difference in abnormal returns associated with cross-border and domestic acquisitions. Consequently, the crossborder effect remains highly significant when bid-specific variables are controlled for. The target company cross-border effect in the UK (over the four month period from $t-2$ to $t+1$ ) amount to somewhere between 6.02 and 9.17 percentage points, depending on which test model is applied.

Cross-Sectional Analysis of Abnormal Returns in Cross-Border Acquisitions

The analysis above reveals that the target company cross-border effect is not 
attributable to the differences in bid characteristics between domestic and cross-border acquisitions. In this section two of the theories put forward in the theoretical framework as to why a target company cross-border effect may be present are tested for the sample of cross-border acquisitions: the EU market access hypothesis (hypothesis 2b), and the exchange rate effect hypothesis (hypothesis 3 ).

Location of cross-border bidder. The takeover bids analyzed in this study took place during the time period leading up to the introduction of the Single European Market in 1992. A large proportion of the cross-border bids appears to have been undertaken in order to gain access to the European Market, and it can be hypothesized that the cross-border effect will be restricted to acquisitions by companies based outside the EU. The market access hypothesis is tested by analyzing whether the level of gains to target company shareholders in cross-border acquisitions is dependent upon whether the bidding company was based within the EU, in other European countries, in the US, or in other overseas countries.

If the target company cross-border effect is attributable to an EU market access premium, one would expect UK target company shareholders to gain more in cross-border acquisitions into the EU than in cross-border acquisitions by companies based in EU countries. As can be seen from Table 7, this is not the case. The coefficients for Non-EU European and US are negative for all models, although generally not statistically significant. This suggests that cross-border acquisitions into the UK by US companies or by companies located in European countries outside the EU result in lower gains to UK targets than do intra-EU acquisitions. The coefficients for the cross-border acquisitions by companies based outside Europe or the US (Rest of World) are small and insignificant. Overall, the results do not support the EU market access hypothesis.

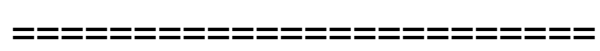

Table 7 about here

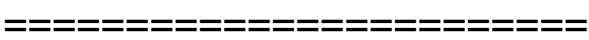

The low gains to UK targets in acquisitions by US bidders may indicate that US bidders, possibly due to the competitive nature of the US takeover market (Conn and 
Connell (1990)), are in some way 'better' than other cross-border bidders, making them able to acquire UK companies at comparatively low prices. However, analysis of bidder returns in cross-border acquisitions into the UK by Danbolt (1995) indicate that US bidders perform no better than other overseas bidders. The cause of the differential wealth effects depending on the location of the overseas bidder still eludes us, and would benefit from further research.

Exchange rate. As argued in the theoretical framework, it can be hypothesized that UK target company shareholders will gain more when Sterling is relatively weak against the currency of the overseas bidding company, although the prior evidence is rather mixed. The mean exchange rate variable (as reported in Table 1) of 0.0080 is somewhat puzzling, indicating that the cross-border acquisitions generally took place when the currency of the acquiring company was marginally 'weak' (relative to previous levels) against Sterling during the bid month.

It can be seen from Table 7 that the coefficient for the exchange rate variable is not statistically significant with any of the five test models. There is therefore no support for the exchange rate hypothesis of UK targets gaining more when the currency of the overseas acquiring company is strong.

The analysis above indicates that the target company cross-border effect is robust to the inclusion of bid specific variables in the cross-sectional analysis, and does not appear to be attributable to either an EU market access premium nor to exchange rate effects. The cause of the target company cross-border effect thus still eludes us. Possible explanations for the differential gains to targets in cross-border and domestic acquisitions include a premium for international diversification, or overpayment, either due to hubris or to pursuit of managerial objectives rather than the maximization of shareholder wealth. Further research, such as an analysis of the joint abnormal returns to targets and bidders in cross-border and domestic acquisitions may be required in order to ascertain whether the high target company returns in cross-border acquisitions reflect the added value of UK targets to overseas bidders, or whether the target company cross-border effect reflects overpayment. 


\section{SUMMARY AND CONCLUSIONS}

This paper has analyzed the abnormal returns to target company shareholders in 510 domestic and 116 cross-border takeover bids for UK listed companies during the 19861991 period. Irrespective of the returns benchmark used (the market model (MM), the capital asset pricing model (CAPM), the index model (IM), and two size-adjusted models, the Hoare-Govett Small Companies model (HGSC), and the size deciles (SD) model), the empirical results are similar. During the period from t-8 to t-3 (where t refers to the month of the bid announcement), target company shareholders in both domestic and cross-border acquisitions suffer negative abnormal returns, indicating that target companies tend to under perform prior to the bid announcement.

During the month of the bid announcement, large and highly significant abnormal returns accrue to shareholders in both domestic (18.35\% to $20.13 \%$, depending on the test model applied) and cross-border targets (19.21\% to $21.38 \%$ ). However, over the four month period from $\mathrm{t}-2$ to $\mathrm{t}+1$, UK target company shareholders gained a significant 5.99 to 11.03 percentage points more in cross-border than in domestic acquisitions (depending on the test model applied).

The level of abnormal returns is found to depend significantly on the bid characteristics, with target company shareholders gaining more in competitive, revised or successful bids, where the bidder offers cash with a loan note alternative, and where the target company is small. However, these and other bid characteristics do not appear to account for the different levels of abnormal returns associated with domestic and crossborder acquisitions. The target company cross-border effect persist at a highly significant 6.02 to 9.17 percentage points when bid characteristics are controlled for.

The cross-border effect is not significantly dependent on where the cross-border bidder is based, and is not exclusive to cross-border acquisitions by companies based outside of the EU. Thus, while the cross-border effect may be a premium for access to the UK market, it does not appear to be attributable to a premium for access to the wider European single market. Similarly, we find no support for the exchange rate effect 
hypothesis, whereby target company returns would depend on the relative strength of Sterling and the currency of the overseas acquiring company. The cause of the crossborder effect thus still eludes us, and further research is required to determine whether the cross-border effect reflects a rational premium for international diversification, or an irrational overpayment consistent with hubris or the pursuit of managerial objectives rather than the maximization of shareholder wealth. 
Appendix

Pearson Correlation Coefficients

Domestic Acquisitions, All Acquisitions (Domestic and Cross-Border), and Cross-Border Acquisitions

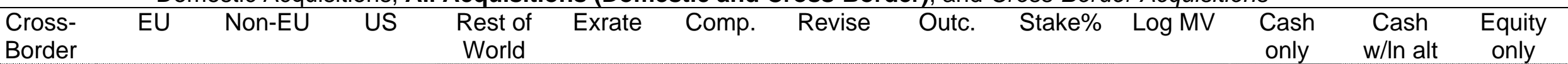

Non-EU

$-0.353^{\star * *}$

US

$-0.327^{* * *}-0.267^{* * *}$

Rest of

World

$-0.406^{\star \star \star} \quad-0.332^{\star \star \star} \quad-0.307^{\star \star *}$

Exchang

e rate

$\begin{array}{llll}-0.061 & -0.097 & 0.115 & 0.051\end{array}$

\begin{tabular}{|c|c|c|c|c|c|c|c|c|c|}
\hline $\begin{array}{l}\text { Competi- } \\
\text { tive }\end{array}$ & -0.010 & -0.088 & 0.037 & 0.146 & -0.075 & -0.025 & & & \\
\hline Revised & 0.019 & 0.009 & -0.035 & -0.074 & 0.089 & 0.011 & $\begin{array}{l}0.189^{\star * \star} \\
\mathbf{0 . 2 1 3}^{\star \star * \star} \\
0.319^{\star \star \star}\end{array}$ & & \\
\hline Outcome & -0.031 & -0.128 & -0.136 & 0.081 & $0.186^{\star \star}$ & 0.096 & $\begin{array}{l}0.131^{\star \star \star} \\
\mathbf{0 . 1 1 2} \\
0.017\end{array}$ & $\begin{array}{l}0.131^{\star \star \star} \\
0.149^{\star \star \star} \\
0.236^{\star \star}\end{array}$ & \\
\hline Stake\% & $0.192^{\star \star \star}$ & -0.127 & 0.075 & -0.024 & 0.082 & 0.125 & $\begin{array}{l}-0.048 \\
-0.063 \\
-0.108\end{array}$ & $\begin{array}{l}-0.027 \\
-0.041 \\
-0.101\end{array}$ & $\begin{array}{c}-0.073^{\star} \\
-0.050 \\
0.041\end{array}$ \\
\hline
\end{tabular}


Appendix - continued

Domestic Acquisitions, All Acquisitionson Correlation Coefficients

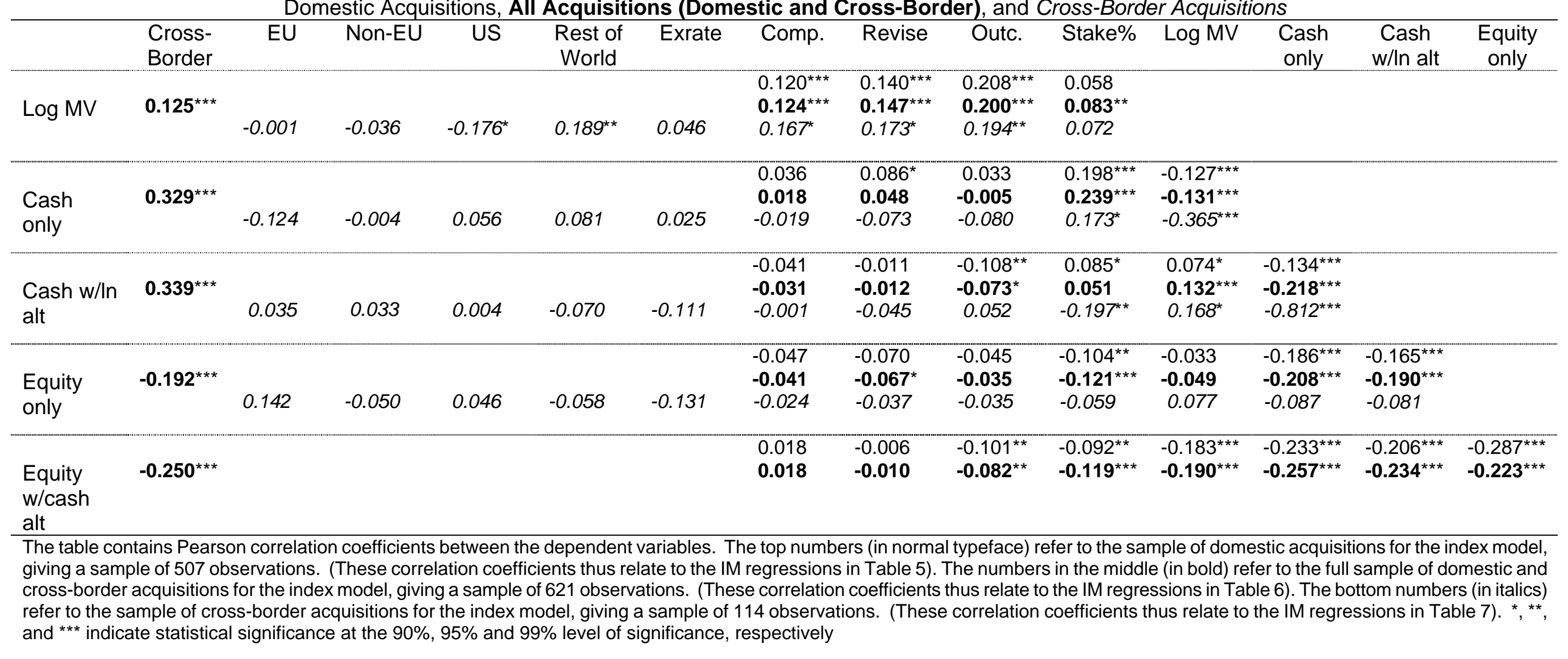





\section{REFERENCES}

Acquisitions Monthly (1986-1991), Tables on Acquisitions of UK Listed Companies, (Tudor House Publications).

Agrawal, A., J.F. Jaffe and G.N. Mandelker (1992), 'The Post-Merger Performance of Acquiring Firms: A Re-examination of an Anomaly', Journal of Finance, Vol. XLVII, No. 4 (September), pp. 1605-1621.

Banz, R.W. (1981), 'The Relationship Between Return and Market Value of Common Stocks', Journal of Financial Economics, Vol. 9, pp. 3-18.

Belsley, D.A., E. Kuh and R.E. Welsch (1980), Regression Diagnostics, John Wiley \& Sons.

Blume, M.E. and R.F. Strambaugh (1983), 'Biases in Corporate Returns - An Application of the Size Effect', Journal of Financial Economics, Vol. 12, pp. 387-404.

Brown, S.J. and J.B. Warner (1980), 'Measuring Security Price Performance', Journal of Financial Economics, Bol. 8, pp. 205-258.

---- and ---- (1985), 'Using Daily Stock Returns - The Case of Event Studies', Journal of Financial Economics, Vol. 14, pp. 3-31.

Cakici, N., C. Hessel, and K. Tandon (1991), 'Foreign Acquisitions in the United States and the Effect on Shareholder Wealth', Journal of International Financial Management and Accounting, Vol. 3, No. 1, pp. 39-60.

Cebenoyan, A.S., G.J. Papaioannou and N.G. Travlos (1992), 'Foreign Takeover Activity in the U.S. and Wealth Effects for Target Firm Shareholders', Financial Management, Vol. 21, Iss. 3 (Autumn), pp. 58-68.

Chatterjee, S. and B. Price (1991), Regression Analysis by Example, $2^{\text {nd }}$ edition, John Wiley \& Sons.

Cheng, L.T.W. and K.C. Chan (1995), 'A Comparative Analysis of the Characteristics of International Takeovers', Journal of Business Finance \& Accounting, Vol. 22, No. 5, pp. 637-657.

Choi, F.D.S. and C. Lee (1991), 'Merger Premia and National Differences in Accounting for Goodwill=, Journal of International Financial Management and Accounting, Vol. 3, No. 3, pp. 219-240.

Conn, R.L. and F. Connell (1990) 'International Mergers: Returns to U.S. and British Firms', Journal of Business Finance \& Accounting, Vol. 17, No. 5, Winter, pp. 689711.

Connell, F. and R.L. Conn (1993), 'A Preliminary Analysis of Shifts in Market Model Regression Parameters in International Mergers Between US and British Firms: 1970-1980', Managerial Finance, Vol. 19, No. 1, pp. 47-77.

Danbolt, J., (1995), 'An Analysis of Gains and Losses to Shareholders of Foreign Bidding Companies Engaged in Cross-Border Acquisitions Into the United Kingdom - 19861991', European Journal of Finance, Vol. 1, No. 3, pp. 279-309.

---- (1996), A Comparative Analysis of the Wealth Effects to Target and Bidding Company Shareholders from Domestic and Cross-Border Acquisitions into the United Kingdom (1986-1991), PhD Thesis (Heriot-Watt University).

Datastream International, (Financial Database).

Davidson, W.N. and L.T.W. Cheng (1997), 'Target Firm Returns: Does the Form of Payment Affect Abnormal Returns?', Journal of Business Finance \& Accounting, Vol. 24, No. 3 and 4, pp. 465-479.

Davis, E.P. (1991), 'International Diversification of Institutional Investors $=$, Bank of England Discussion Papers, Technical Series, No. 44 (September), pp. 10-16.

De, S., M. Fedenia and A.J. Triantis (1996), 'Effects of Competition on Bidder Returns', Journal of Corporate Finance, Vol. 2, pp. 261-282.

Dewenter, K.L. (1995a), 'Does the Market React Differently to Domestic and Foreign Takeover Announcements? Evidence from the U.S. Chemical and Retail Industries', Journal of Financial Economics, Vol. 37, pp. 421-441.

---- (1995b), 'Do Exchange Rate Changes Drive Foreign Investment in US', Journal of 
Business, Vol. 68, No. 3 (July), pp. 405-433.

Dimson, E. and P. Fraletti (1986), 'Brokers' Recommendations: The Value of a Telephone

Tip', The Economic Journal, Vol. 96, pp. 139-159.

and P. Marsh (1986), 'Event Study Methodologies and the Size Effect', Journal of Financial Economics, Vol. 17, pp. 113-142.

Department of Trade and Industry (DTI) (1991), Competition Policy - How it Works, HMSO.

Eun, C.S., R. Kolodny and C. Scheraga (1995), Cross-Border Acquisitions and Shareholder Wealth: Tests of the Synergy Hypothesis, Working paper, (Georgia Institute of Technology/University of Maryland).

Fama, E.F., L. Fisher, M.C. Jensen and R. Roll (1969), 'The Adjustment of Stock Prices to New Information', International Economic Review, Vol. 10, No. 1 (February), pp. 121.

---- and K.R. French (1996), 'Multifactor Explanations of Asset Pricing Anomalies', Journal of Finance, Vol. 50, pp. 131-155.

Fatemi, A.M. (1984), 'Shareholder Benefits from Corporate International Diversification=, Journal of Finance, Vol. XXXIX, No. 5 (December, pp. 1325-1344.

---- and E.P.H. Furtado (1988), 'An Empirical Investigation of the Wealth Effects of Foreign Acquisitions', in S.J. Khoury and A. Ghosh (Eds.), Recent Developments in International Banking and Finance, Vol. 2, Lexington Books, pp. 363-379.

Feils, D.J. (1993), Shareholder Wealth Effects of International Mergers and Acquisitions: Evidence from the United States, the United Kingdom, and Germany, PhD Thesis (University of South Carolina).

Firth, M. (1991), 'Corporate Takeovers, Shareholder Returns and Executive Rewards=, Managerial and Decision Economics, Vol. 12, pp. 421-428.

Franks, J.R., J.E. Broyles and M.J. Hecht (1977), 'An Industry Study of the Profitability of Mergers in the United Kingdom=, Journal of Finance, Vol. XXXII, No. 5, December, pp. 1513-1525.

---- and R.S. Harris (1989), 'Shareholder Wealth Effects of Corporate Takeovers - The UK Experience 1955-1985', Journal of Financial Economics, Vol. 23, pp. 225-249.

----, R.S. Harris and C. Mayer (1988), 'Means of Payment in Takeovers: Results for the United Kingdom and the United States', in A.J. Auerbach.(Ed.), Corporate Takeovers: Causes \& Consequences, University of Chicago Press, Chicago, pp. 221-263.

----, R.S. Harris and S. Titman (1991), 'The Post-Merger Share-Price Performance of Acquiring Firms', Journal of Financial Economics, Vol. 29, pp. 81-96.

Froot, K.A. and J.C. Stein (1991), 'Exchange Rates and Foreign Direct Investment: An Imperfect Capital Markets Approach=, Quarterly Journal of Economics, Vol. 106, pp. 1191-1217.

Geroski, P. and A. Vlassopoulos (1990), 'European Merger Activity: A Response to 1992?=, in Continental Mergers are Different: Strategy and Policy for 1992, Centre for Business Strategy (London Business School), pp. 22-46.

Gregory, A. (1997), 'An Examination of the Long Run Performance of UK Acquiring Firms=, Journal of Business Finance \& Accounting, Vol. 24, No. 7\&8, pp. 971-1002.

Gujarati, D.N. (1988), Basic Econometrics, $2^{\text {nd }}$ edition, McGraw-Hill.

Harris, R.S. and D. Ravenscraft (1991), 'The Role of Acquisitions in Foreign Direct Investment: Evidence from the U.S. Stock Market', Journal of Finance, Vol. XLVI, No. 3 (July), pp. 825-844.

Higson, C. and J. Elliott (1998), 'Post-Takeover Returns: The UK Evidence=, Journal of Empirical Finance, Vol. 5, No. 1, pp. 27-46.

Hisey, K.B. and R.E. Caves (1985), 'Diversification Strategy and Choice of Country: Diversifying Acquisitions Abroad by U.S. Multinationals, 1978-1980', Journal of International Business Studies, Vol. 15 (Summer), pp. 51-64.

Huang, Y.S. and R.A. Walkling (1987), 'Target Abnormal Returns Associated with Acquisition Announcements - Payment, Acquisition Form, and Managerial Resistance', Journal of Financial Economics, Vol. 19, pp. 329-349. 
Hymer, S.H. (1976), The International Operations of National Firms: A Study of Direct Foreign Investment, MIT Press, Cambridge, Massachusetts.

Jacquemin, A., P. Buigues and F. Ilzkocitz (1989), 'Horizontal Mergers and Competition Policy in the European Community=, European Economy, No. 40, Commission of the European Communities, Directorate-General for Economic and Financial Affairs (May), pp. 1-57.

Jacquillat, B. and B. Solnik (1978), 'Multinationals are Poor Tools for Diversification=, Journal of Portfolio Management (Winter), pp. 8-12.

Jensen, M.C. and R.S. Ruback (1983), 'The Market for Corporate Control - The Scientific Evidence' Journal of Financial Economics, Vol. 11, pp.5-50.

Kang, J-K, (1993) 'The International Market for Corporate Control - Mergers and Acquisitions of U.S. Firms by Japanese Firms', Journal of Financial Economics, Vol. 34, pp. 345-371.

Kaplan, S.N. and M.S. Weisback (1992), 'The Success of Acquisitions: Evidence from Divestitures', Journal of Finance, Vol. XLVII, No. 1 (March), pp. 107-138.

Keim, D. (1983), 'Size-related Anomalies and Stock Return Seasonality: Further Empirical Evidence', Journal of Financial Economics, Vol. 12 (June), pp. 13-32.

Kennedy, V.A. and R.J. Limmack (1996), 'Takeover Activity, CEO Turnover, and the Market for Corporate Control=, Journal of Business Finance \& Accounting, Vol. 23, No. 2 (March), pp. 267-285.

Lessard, D. (1993), 'Comment= to D.L. Swenson, 'Foreign Mergers and Acquisitions in the United States=, in K.A. Froot (Ed.), Foreign Direct Investment (University of Chicago Press), pp. 282-283.

Limmack, R.J. (1991), 'Corporate Mergers and Shareholder Wealth Effects: 1977-1986', Accounting and Business Research, Vol. 21, No. 83, pp. 239-251.

London Business School (1985-1991) (Edited by E. Dimson and P.R. Marsh), Risk Measurement Service, Vol. 7-13, Institute of Finance and Accounting.

---- Share Price Database, (Financial Database).

Markides, C.C. and C.D. Ittner (1994), 'Shareholder Benefits from Corporate International Diversification: Evidence from U.S. International Acquisitions=, Journal of International Business Studies (Second Quarter), pp. 343-366.

Marr, M.W. Jr., S. Mohta and M.F. Spivey (1993), 'An Analysis of Foreign Takeovers in the United States', Managerial and Decision Economics, Vol. 14, No. 4 (Jul/Aug), pp. 285-294.

Martin, K.J. (1996), 'The Method of Payment in Corporate Acquisitions, Investment Opportunities, and Managerial Ownership=, Journal of Finance, Vol. LI, No. 4 (September), pp. 1227-1246.

Michel, A. and I. Shaked (1986), 'Multinational Corporations vs. Domestic Corporations: Financial Performance and Characteristics', Journal of International Business Studies, Vol. 17 (Fall), pp. 89-100.

Montgomery, D.C. and E.A. Peck (1982), Introduction to Linear Regression Analysis, John Wiley \& Sons.

Morgan, E.V. and A.D. Morgan (1990), The Stock Market and Mergers in the United Kingdom, The David Hume Institute, Hume Occasional Paper No. 24.

Panel on Takeovers and Mergers, (1990), The City Code on Takeovers and Mergers and The Rules Governing Substantial Acquisition of Shares.

Park, R.E. (1966), 'Estimation with Heteroscedastic Error Terms', Econometrica, Vol. 34, No. 4 (October), p. 888.

Patell, J.M. (1976), 'Corporate Forecasts of Earnings Per Share and Stock Price Behavior: Empirical Tests', Journal of Accounting Research, Vol. 14, pp. 246-276.

Peterson, D.R. and P.P. Peterson (1991), 'The Medium of Exchange in Mergers and Acquisitions', Journal of Banking and Finance, Vol. 15, pp. 383-405.

Pringle, R. (1991), The Control of Mergers and Takeovers in the EC, The David Hume Institute, Hume Occasional Paper No. 29.

Reinganum, M.R. (1981), `Abnormal Returns to Small Firm Portfolios', Financial Analysts 
Journal, (March-April), pp. 52-56.

Roll, R. (1986), 'The Hubris Hypothesis of Corporate Takeovers', Journal of Business, Vol. 59, No. 2, Pt. 1, pp. 197-216.

Servaes, H. (1991), 'Tobin's $Q$ and the Gains from Takeovers', Journal of Finance, Vol. LXVI, No. 1 (March), pp. 409-419.

---- and M. Zenner (1990), The Returns to Foreign Acquisitions in the United States, Centre for Research in Security Prices, Working Paper No. 302, (University of Chicago).

Shaked, I., A. Michel and D. McClain (1991), 'The Foreign Acquirer Bonanza: Myth or Reality?', Journal of Business Finance \& Accounting, Vol. 18, No. 3 (April), pp. 431447.

Shapiro, A.C. (1999), Multinational Financial Management, 6th international edition, Prentice Hall.

Solnik, B.H. (1974), 'Why Not Diversify Internationally Rather Than Domestically?=, Financial Analysts Journal (July/August), pp. 48-54. Reproduced in Financial Analysts Journal (January/February), 1995, pp. 89-94.

---- (1996), International Investments, 3rd edition, Addision-Wesley.

Song, K.P. (1993), Value Creation in Cross-Border Acquisitions, Ph.D. Thesis, (University of Houston).

Strong, N.C. (1992), 'Modelling Abnormal Returns: A Review Article', Journal of Business Finance \& Accounting, Vol. 19, No. 4 (June), pp. 533-553.

Stulz, R.M., R.A. Walkling and M.H. Song (1990), 'The Distribution of Target Ownership and the Distribution of Gains in Successful Takeovers', Journal of Finance, Vol. XLV, No. 3 (July), pp. 817-833.

Sudarsanam, P.S. (1995), The Essence of Mergers and Acquisitions (Prentice Hall).

----, P. Holl and A. Salami (1996), 'Shareholder Wealth Gains in Mergers: Effect of Synergy and Ownership Structure=, Journal of Business Finance \& Accounting, Vol. 23, No. 5\&6, pp. 673-698.

Sudia, J.A. (1992), Valuation Effects of Takeover Regulation on Multinational Bidders, D.B.A. Thesis, (University of Colorado at Boulder).

Swenson, D.L. (1993), 'Foreign Mergers and Acquisitions in the United States', in Froot, K.A. (Ed.), Foreign Direct Investment (University of Chicago Press), pp. 255- 281.

Tessema, A. (1985), Effect of International Mergers and Acquisitions on Shareholder Returns of Participating U.S. Firms, PhD Thesis, (University of lowa).

Travlos, N. (1987), 'Corporate Takeover Bids, Methods of Payment, and Bidding Firms' Stock Returns', Journal of Finance, Vol. XLII, No. 4 (September), pp. 943-963.

Vasconcellos, G.M., and R.J. Kish (1998), 'Cross-Border Mergers and Acquisitions: The European-US Experience $=$, Journal of Multinational Financial Management, Vol. 8, pp. 431-450.

Wansley, J.W., W.R. Lane and H.C. Yang (1983), 'Shareholder Returns to USA Acquired Firms and Domestic Acquisitions', Journal of Business Finance \& Accounting, Vol. 10, No. 4, pp. 647-656.

----, ---- and ---- (1987), 'Gains to Bidder Firms in Cash and Security Transactions', The Financial Review, Vol. 22, pp. 403-414.

Weiss, N.A. and M.J. Hassett (1986), Introductory Statistics, Second Edition (AddisonWesley Company). 
Table 1

Sample Characteristics

\begin{tabular}{|c|c|c|c|}
\hline Sample & & $\begin{array}{r}\text { Cross-Border } \\
116\end{array}$ & $\begin{array}{r}\text { Domestic } \\
510\end{array}$ \\
\hline Region & $\begin{array}{l}\text { EU } \\
\text { Non-EU European } \\
\text { US } \\
\text { Rest of the World }\end{array}$ & $\begin{array}{l}30.2 \% \\
22.4 \% \\
19.8 \% \\
27.6 \%\end{array}$ & \\
\hline Payment & $\begin{array}{l}\text { Cash bids } \\
\text { Cash only } \\
\text { Cash w/full loan alt. } \\
\text { Cash w/other alts. } \\
\text { Equity bids } \\
\text { Equity only } \\
\text { Equity w/full cash alt. } \\
\text { Equity w/other alts. } \\
\text { Mixed and other bids } \\
\text { Cash\&equity only } \\
\text { Cash\&equity w/full cash alt. } \\
\text { Cash\&equity w/other alts. } \\
\text { Other bids }\end{array}$ & $\begin{array}{r}94.0 \% \\
46.6 \% \\
43.1 \% \\
4.3 \% \\
1.7 \% \\
0.9 \% \\
0.0 \% \\
0.9 \% \\
4.3 \% \\
2.6 \% \\
0.0 \% \\
0.0 \% \\
1.7 \%\end{array}$ & $\begin{aligned} 29.4 \% & \\
13.1 \% & \\
10.6 \% & \\
5.7 \% & \\
49.2 \% & \\
18.6 \% & \\
26.5 \% & \\
4.1 \% & \\
21.4 \% & \\
3.1 \% & \\
3.7 \% & \\
1.8 \% & \\
12.8 \% & \end{aligned}$ \\
\hline Competitive & $\begin{array}{l}\text { Single bidder } \\
\text { Multiple bidders }\end{array}$ & $\begin{array}{r}94.0 \% \\
6.0 \%\end{array}$ & $\begin{array}{l}86.2 \% \text { a) * } \\
13.6 \%\end{array}$ \\
\hline Revised & $\begin{array}{l}\text { Not revised } \\
\text { Offer revised }\end{array}$ & $\begin{array}{l}86.2 \% \\
13.8 \%\end{array}$ & $\begin{array}{l}86.2 \% \text { a) } \\
13.8 \%\end{array}$ \\
\hline Outcome & $\begin{array}{l}\text { Successful } \\
\text { Failed }\end{array}$ & $\begin{array}{l}87.9 \% \\
12.1 \%\end{array}$ & $\begin{array}{l}79.9 \% \text { a) } \\
20.1 \%\end{array}$ \\
\hline Stake & $\begin{array}{l}\text { No pre-bid sake } \\
\text { Pre-bid stake }\end{array}$ & $\begin{array}{l}56.0 \% \\
44.0 \%\end{array}$ & $\begin{array}{l}76.2 \% \text { a) } \star \star \star \\
23.8 \%\end{array}$ \\
\hline Stake\% & Mean stake (all companies) & $15.2 \%$ & 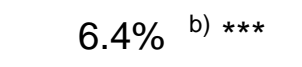 \\
\hline$M V$ & Mean pre-bid market value & ,151.8m & ,104.6m \\
\hline Ex rate & Mean exchange rate value & 0.0080 & n.a. c) \\
\hline
\end{tabular}

EU refers to cross-border bids by companies based in countries which were members of the European Community at the time of the acquisition, Non-EU European to bids by companies based in other European countries, US to bids by US companies, and Rest of the World to acquisitions by companies based outside of Europe and the US. The method of payment is classified depending on the method of payment offered in the final bid. Loan alt refers to where the offer contained a full loan note alternative. Competitive is a dummy variable taking the value 0 if there was a single bidder and 1 if more than one company bid for the target (competitive bid), Revised is a dummy variable taking the value 0 if the offer was not revised and 1 if the terms of the offer were revised (terms of the offer improved by increasing the offer price and/or adding more choice with regard to the method of payment), Outcome is a dummy variable taking the value 0 if the bid was successful (in that the bidding company obtained control of the target company) and 1 if the offer failed, Stake \% refers to the percentage holding by the bidding company in the target company at the time of the bid announcement, MV is the pre-bid market capitalization of equity of the target company (in the cross-sectional analysis the log of the MV is used), and Exchange rate refers to the deviation from the average exchange rate over the two year period prior to the month of the bid announcement (values below zero indicating foreign exchange rate being 'strong' (compared to previous exchange rates) relative to Sterling). * ${ }^{* \star}$, and *** indicate statistical significance at $90 \%, 95 \%$ and $99 \%$ level of significance, respectively. Tested using a) Chi-squared, b) difference of mean t-test, and c) t-test. d) Differences in the method of payment offered in domestic and cross-border acquisitions is tested using the three headline pay categories and the ten pay subcategories (both tests highly statistically significant). 
Table 2

Domestic Acquisitions

\begin{tabular}{|c|c|c|c|c|c|}
\hline Month & IM & MM & CAPM & HGSC & SD \\
\hline Sample & 510 & 389 & 389 & 389 & 507 \\
\hline$t-8$ & $-0.0136^{\star \star \star}$ & $-0.0168^{\star * \star}$ & -0.0140 ** & $-0.0157^{\star \star \star}$ & $-0.0167^{\star \star *}$ \\
\hline $\mathrm{t}-7$ & $-0.0115^{\star \star}$ & -0.0088 & -0.0063 & -0.0060 & $-0.0151^{* \star *}$ \\
\hline$t-6$ & -0.0038 & $-0.0068^{c}$ & -0.0045 & $-0.0090^{c}$ & $-0.0107^{* *}$ \\
\hline$t-5$ & -0.0054 & -0.0042 & -0.0019 & -0.0064 & $-0.0112^{\star \star}$ \\
\hline$t-4$ & -0.0074 & -0.0042 & -0.0017 & -0.0024 & $-0.0127^{* \star *}$ \\
\hline$t-3$ & $-0.0155^{\star \star \star}$ & $-0.0172^{\star \star \star}$ & $-0.0152^{\star \star}$ & $-0.0167^{\star \star \star}$ & $-0.0231^{* \star *}$ \\
\hline$t-2$ & 0.0075 & 0.0106 & $0.0128^{*}$ & 0.0077 & 0.0019 \\
\hline$t-1$ & $0.0381^{\star * *}$ & $0.0392^{* * *}$ & $0.0415^{\star \star *}$ & $0.0366^{* * *}$ & $0.0293^{* * *}$ \\
\hline $\mathrm{t}$ & $0.1939 * * *$ & $0.1990 * \star *$ & $0.2013^{\star \star *}$ & $0.1973^{\star \star *}$ & $0.1835^{\star * *}$ \\
\hline$t+1$ & 0.0014 & -0.0023 & 0.0004 & -0.0036 & -0.0059 \\
\hline$t+2$ & -0.0027 & -0.0039 & -0.0028 & -0.0049 & $-0.0059 \star^{b}$ \\
\hline$t+3$ & $-0.0058^{\star * * \mathrm{~b}}$ & $-0.0067 * * b$ & $-0.0061^{* * b}$ & $-0.0062^{* * b}$ & $-0.0055^{* * b}$ \\
\hline$t+4$ & -0.0037 & -0.0058 & -0.0053 & $-0.0060 * \mathrm{~b}$ & $-0.0058 * * b$ \\
\hline$t+5$ & 0.0013 & 0.0017 & 0.0023 & 0.0019 & 0.0000 \\
\hline
\end{tabular}

Average abnormal returns to shareholders of UK companies which received domestic takeover bids. The abnormal returns are calculated using 5 different test models: IM refers to the index model, MM to the market model, CAPM to the capital asset pricing model, HGSC to the Hoare Govett small companies index model, and SD to the size deciles index model (Models as specified in equations 1-5). Time periods refer to months relative to the month of the bid announcement, which is denoted t. Not all target companies remained listed during the months following the takeover bids. In these cases, the return on the share has been assumed to be equal to the benchmark (i.e., abnormal return of zero). The level of statistical significance of the equally weighted cumulative abnormal returns, is tested using the crosssectional t-test (Strong (1992)). Following Strong (1992), the Patell Standardized Residual (PSR) Test (Patell (1976)) is applied for the market model. * ***, and *** indicate statistical significance at 90\%, 95\% and $99 \%$ level of significance, respectively. b) While significant using parametric statistics, the coefficient is not statistically significant using Wilcoxon signed-rank nonparametric test of the median. c) While not significant using parametric statistics, the coefficient is statistically significant using Wilcoxon signed-rank nonparametric test of the median. 
Table 3

Cross-Border Acquisitions

\begin{tabular}{|c|c|c|c|c|c|}
\hline Month & IM & MM & CAPM & HGSC & SD \\
\hline Sample & 116 & 96 & 96 & 96 & 114 \\
\hline$t-8$ & $-0.0152^{c}$ & -0.0167 & $-0.0200 *$ & -0.0164 & -0.0120 \\
\hline$t-7$ & -0.0131 & -0.0037 & -0.0055 & -0.0030 & -0.0096 \\
\hline$t-6$ & -0.0023 & 0.0030 & 0.0047 & 0.0045 & -0.0025 \\
\hline$t-5$ & $-0.0188^{\star b}$ & -0.0080 & -0.0074 & -0.0028 & -0.0126 \\
\hline$t-4$ & $-0.0272^{\star *}$ & -0.0135 & -0.0168 & -0.0095 & -0.0186 \\
\hline$t-3$ & $-0.0222^{\star \star}$ & -0.0097 & -0.0116 & -0.0053 & $-0.0195^{\star \star}$ \\
\hline$t-2$ & $0.0307^{* \star b}$ & $0.0254^{*^{b}}$ & 0.0221 & $0.0301 *^{\mathrm{b}}$ & $0.0343^{* *}$ \\
\hline$t-1$ & $0.0666^{\star * *}$ & $0.0691^{* * *}$ & $0.0659 * \star *$ & $0.0672^{\star * *}$ & $0.0644^{* * *}$ \\
\hline $\mathrm{t}$ & $0.1928 * * *$ & $0.2138 * \star *$ & $0.2033^{\star * *}$ & $0.2102^{\star * *}$ & $0.1921^{* * *}$ \\
\hline$t+1$ & $0.0224^{* * b}$ & 0.0104 & $0.0246 \star^{b}$ & 0.0161 & $0.0283^{* * b}$ \\
\hline$t+2$ & 0.0045 & 0.0041 & 0.0015 & 0.0075 & 0.0092 \\
\hline$t+3$ & $-0.0110^{\star * \star * b}$ & $-0.0130 * * \star b$ & $-0.0094^{* * b}$ & $-0.0115^{\star * b}$ & $-0.0104^{\star * \star \hbar}$ \\
\hline$t+4$ & $-0.0087^{* \mathrm{~b}}$ & $-0.0106^{* b}$ & $-0.0108^{\star b}$ & -0.0084 & -0.0072 \\
\hline$t+5$ & 0.0021 & 0.0014 & 0.0018 & 0.0003 & -0.0012 \\
\hline
\end{tabular}

Average abnormal returns to shareholders of UK companies which received takeover bids from overseas companies. The abnormal returns are calculated using 5 different test models: IM refers to the index model, MM to the market model, CAPM to the capital asset pricing model, HGSC to the Hoare Govett small companies index model, and SD to the size deciles index model (Models as specified in equations 1-5). Time periods refer to months relative to the month of the bid announcement, which is denoted t. Not all target companies remained listed during the months following the takeover bids. In these cases, the return on the share has been assumed to be equal to the benchmark (i.e., abnormal return of zero). Following Strong (1992), the Patell Standardized Residual (PSR) Test (Patell (1976)) is applied for the market model. *,**, and *** indicate statistical significance at 90\%, 95\% and 99\% level of significance, respectively. b) While significant using parametric statistics, the coefficient is not statistically significant using Wilcoxon signed-rank nonparametric test of the median. c) While not significant using parametric statistics, the coefficient is statistically significant using Wilcoxon signed-rank nonparametric test of the median. 
Table 4

Cross-Border Effect

\begin{tabular}{|c|c|c|c|c|c|}
\hline Month & IM & MM & CAPM & HGSC & SD \\
\hline Sample & 626 & 485 & 485 & 485 & 621 \\
\hline$t-8$ & -0.0016 & 0.0001 & -0.0060 & -0.0007 & 0.0047 \\
\hline $\mathrm{t}-7$ & -0.0016 & 0.0051 & 0.0008 & 0.0030 & 0.0055 \\
\hline$t-6$ & 0.0015 & 0.0098 & 0.0092 & 0.0135 & 0.0082 \\
\hline$t-5$ & -0.0134 & -0.0038 & -0.0056 & 0.0036 & -0.0011 \\
\hline $\mathrm{t}-4$ & -0.0198 & -0.0093 & -0.0151 & -0.0071 & -0.0059 \\
\hline$t-3$ & -0.0067 & 0.0075 & 0.0036 & 0.0115 & 0.0036 \\
\hline $\mathrm{t}-2$ & 0.0232 & 0.0148 & 0.0093 & 0.0225 & $0.0324^{\star *}$ \\
\hline t-1 & $0.0286^{*}$ & $0.0299 *$ & 0.0244 & $0.0306^{*}$ & $0.0351^{* *}$ \\
\hline $\mathrm{t}$ & -0.0011 & 0.0148 & 0.0020 & 0.0130 & 0.0086 \\
\hline$t+1$ & $0.0210^{*}$ & 0.0127 & $0.0242^{*}$ & $0.0197^{*}$ & $0.0342^{\star \star \star}$ \\
\hline$t+2$ & 0.0072 & 0.0080 & 0.0044 & 0.0123 & $0.0151^{* *}$ \\
\hline$t+3$ & -0.0051 & -0.0063 & -0.0033 & -0.0053 & -0.0049 \\
\hline$t+4$ & -0.0051 & -0.0048 & -0.0056 & -0.0023 & -0.0013 \\
\hline$t+5$ & 0.0007 & -0.0004 & -0.0004 & -0.0016 & -0.0012 \\
\hline
\end{tabular}

Average abnormal returns to shareholders of UK companies which received takeover bids from overseas companies less the abnormal returns to UK target shareholders in domestic acquisition (Target company cross-border effect). The abnormal returns are calculated using 5 different test models: IM refers to the index model, MM to the market model, CAPM to the capital asset pricing model, HGSC to the Hoare Govett small companies index model, and SD to the size deciles index model (Models as specified in equations 1-5). Time periods refer to months relative to the month of the bid announcement, which is denoted t. Not all target companies remained listed during the months following the takeover bids. In these cases, the return on the share has been assumed to be equal to the benchmark (i.e., abnormal return of zero). The differences in abnormal returns in cross-border and domestic acquisitions is tested using a two-sample difference in mean t-test (Weiss and Hassett (1986)). *,**, and $* \star *$ indicate statistical significance at $90 \%, 95 \%$ and $99 \%$ level of significance, respectively. 
Table 5

Cross-Sectional Analysis of CAR-2,+1

Domestic Targets

\begin{tabular}{|c|c|c|c|c|c|c|c|c|c|c|c|c|c|c|c|}
\hline & \multicolumn{3}{|c|}{ IM } & \multicolumn{3}{|c|}{ MM } & \multicolumn{3}{|c|}{ CAPM } & \multicolumn{3}{|c|}{ HGSC } & \multicolumn{3}{|c|}{ SD } \\
\hline & & $p$-value & VIF & Coef. & $p$-value & VIF & Coef. & $p$-value & VIF & Coef. & $p$-value & VIF & Coef. & $p$-value & VIF \\
\hline & $\begin{array}{l}\text { Coef. } \\
0.3171\end{array}$ & 0.000 & & 0.3611 & 0.000 & & 0.3535 & 0.000 & & 0.3383 & 0.000 & & 0.2639 & 0.000 & \\
\hline Competitive & 0.1173 & 0.010 & 1.1 & 0.0871 & 0.054 & 1.1 & 0.1037 & 0.022 & 1.1 & 0.0841 & 0.055 & 1.1 & $0.0861^{b}$ & 0.064 & 1.1 \\
\hline Revised & 0.0702 & 0.045 & 1.1 & 0.0633 & 0.069 & 1.1 & 0.0572 & 0.100 & 1.1 & 0.0567 & 0.094 & 1.1 & 0.0691 & 0.050 & 1.1 \\
\hline Outcome & -0.0639 & 0.051 & 1.1 & -0.0254 & 0.446 & 1.1 & -0.0313 & 0.346 & 1.1 & -0.0347 & 0.284 & 1.1 & -0.0540 & 0.099 & 1.1 \\
\hline Stake\% & -0.0001 & 0.926 & 1.1 & -0.0002 & 0.772 & 1.1 & -0.0001 & 0.924 & 1.1 & -0.0000 & 0.933 & 1.1 & -0.0004 & 0.558 & 1.1 \\
\hline Log MV & -0.0176 & 0.024 & 1.2 & -0.0295 & 0.000 & 1.2 & -0.0230 & 0.005 & 1.2 & -0.0212 & 0.008 & 1.2 & -0.0054 & 0.490 & 1.2 \\
\hline Cash only & -0.0509 & 0.181 & 1.4 & -0.0953 & 0.019 & 1.4 & -0.1119 & 0.006 & 1.4 & -0.1135 & 0.004 & 1.4 & -0.0605 & 0.114 & 1.4 \\
\hline Cash w/ln alt & 0.0291 & 0.469 & 1.2 & 0.0288 & 0.542 & 1.2 & 0.0318 & 0.501 & 1.2 & 0.0552 & 0.230 & 1.2 & 0.0736 & 0.068 & 1.2 \\
\hline Equity only & -0.1411 & 0.000 & 1.3 & -0.0952 & 0.010 & 1.3 & -0.1132 & 0.002 & 1.3 & -0.1265 & 0.000 & 1.3 & -0.1654 & 0.000 & 1.4 \\
\hline Equity w/cash alt & 0.0133 & 0.663 & 1.5 & 0.0039 & 0.905 & 1.5 & 0.0032 & 0.921 & 1.5 & -0.0181 & 0.570 & 1.5 & -0.0378 & 0.215 & 1.5 \\
\hline Observations $^{\mathrm{a}}$ & 507 & & & 386 & & & 386 & & & 386 & & & 507 & & \\
\hline Adjusted $\mathrm{R}^{2}$ & $7.3 \%$ & & & $6.0 \%$ & & & $6.4 \%$ & & & $6.7 \%$ & & & $7.5 \%$ & & \\
\hline$F$-value & 5.40 & 0.000 & & 3.75 & 0.000 & & 3.95 & 0.000 & & 4.05 & 0.000 & & 5.56 & 0.000 & \\
\hline Park-test $F$-value & 1.12 & 0.345 & & 1.09 & 0.372 & & 1.10 & 0.364 & & 0.99 & 0.451 & & 0.52 & 0.857 & \\
\hline
\end{tabular}

Table contains regression output from cross-sectional analysis of cumulative abnormal returns (over months $\mathrm{t}-2 \mathrm{to} t+1$ ) to target company shareholders in domestic UK acquisitions using the following regression equation: CARi $i_{2+1}=\alpha+\beta_{1}$ Competitive $+\beta_{2}$ Revised $+\beta_{3}$ Outcome $+\beta_{4}$ Stake $\%+\beta_{5} L$ ogMV $+\beta_{6}$ Cash $+\beta_{7}$ Cash $w / l n+\beta_{3}$ Equity $+\beta_{9}$ Equity $w /$ cash $+\mu$. Variables as defined in Table 4. Cash w/ln alt refers to where there is a full loan note alternative to the cash offer, while equity w/cash alt refers to where there is a full cash alternative to the equity offer. Due to the small sample sizes for some of the payment categories, coefficients for dummy variables have been estimated with four pay categories (the other pay categories have been combined, and are captured by the constant). VIF refers to the variance inflation factor. a) Some of the cross-sectional variables were not available for all companies, thus reducing sample sizes. b) While significant using OLS, the coefficient is not significant using robust (rank) regression. 
Table 6

Cross-Sectional Analysis of CAR-2,+1

Cross-Border Effect

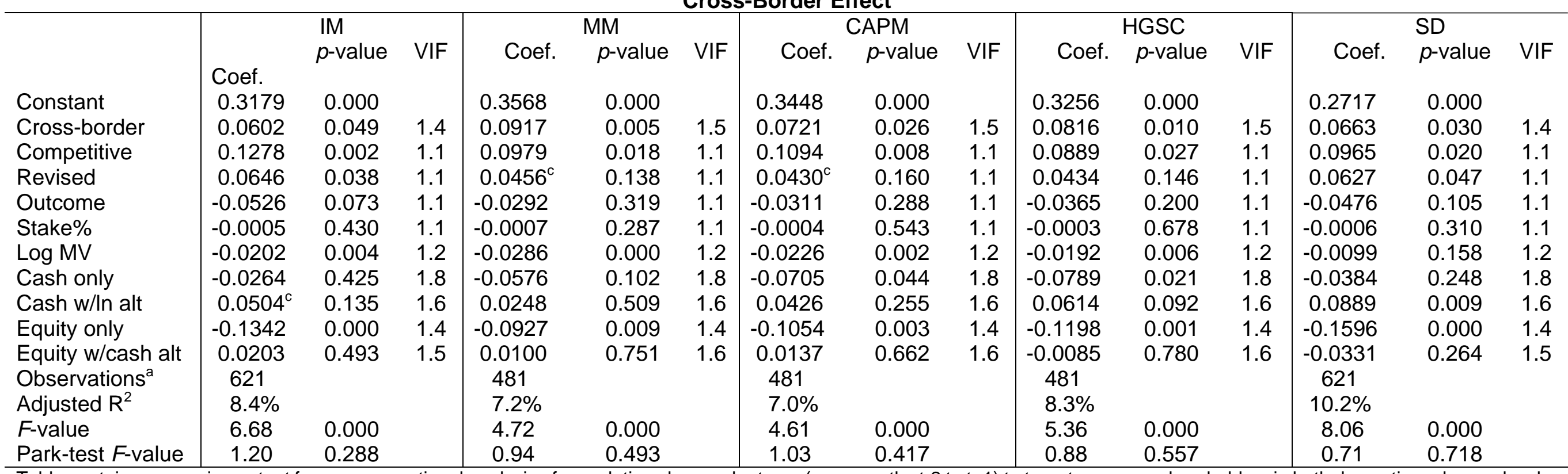

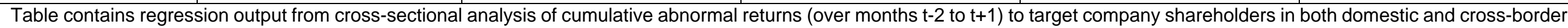

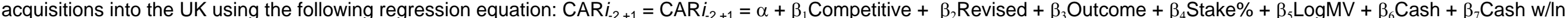

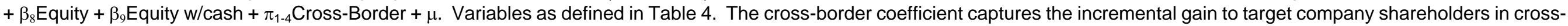

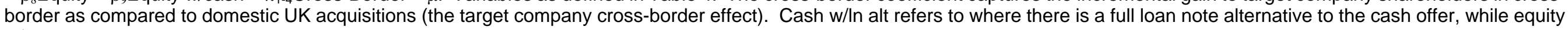

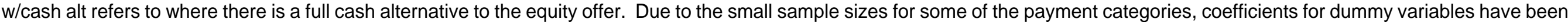

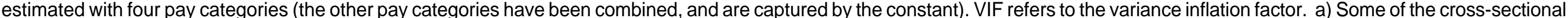
variables were not available for all companies, thus reducing sample sizes. c) While not significant using OLS, the coefficient is significant using robust (rank) regression. 
Table 7

Cross-Sectional Analysis of CAR-2,+1

Cross-Border Targets

\begin{tabular}{|c|c|c|c|c|c|c|c|c|c|c|c|c|c|c|c|}
\hline & \multirow{2}{*}{\multicolumn{12}{|c|}{ CAPM }} & \multirow{2}{*}{\multicolumn{3}{|c|}{ SD }} \\
\hline & & & & & & & & & & & & & & & \\
\hline & & $p$-value & VIF & Coef. & $p$-value & VIF & Coef. & $p$-value & VIF & Coef. & $p$-value & VIF & Coef. & $p$-value & VIF \\
\hline Constant & $\begin{array}{l}\text { Coef. } \\
0.3216\end{array}$ & 0.005 & & 0.3811 & 0.001 & & 0.2577 & 0.023 & & 0.2653 & 0.019 & & 0.3223 & 0.004 & \\
\hline Non-EU Europe & -0.0872 & 0.162 & 1.4 & $-0.1016^{c}$ & 0.118 & 1.4 & -0.0826 & 0.191 & 1.4 & -0.0689 & 0.274 & 1.4 & -0.0741 & 0.240 & 1.4 \\
\hline US & -0.0093 & 0.890 & 1.5 & -0.1138 & 0.093 & 1.5 & -0.0699 & 0.287 & 1.5 & -0.0632 & 0.334 & 1.5 & -0.0115 & 0.865 & 1.5 \\
\hline Rest of World & 0.0416 & 0.491 & 1.5 & -0.0245 & 0.691 & 1.6 & 0.0297 & 0.621 & 1.6 & 0.0238 & 0.691 & 1.6 & 0.0327 & 0.595 & 1.5 \\
\hline Exchange rate & -0.0260 & 0.922 & 1.1 & 0.1172 & 0.667 & 1.2 & 0.1688 & 0.525 & 1.2 & -0.0070 & 0.979 & 1.2 & -0.0754 & 0.785 & 1.1 \\
\hline Competitive & 0.2244 & 0.035 & 1.2 & $0.2008^{b}$ & 0.077 & 1.3 & 0.1983 & 0.073 & 1.3 & 0.1543 & 0.161 & 1.3 & 0.1789 & 0.072 & 1.3 \\
\hline Revised & 0.0505 & 0.485 & 1.3 & -0.0321 & 0.648 & 1.3 & -0.0002 & 0.997 & 1.3 & -0.0028 & 0.967 & 1.3 & 0.0416 & 0.573 & 1.2 \\
\hline Outcome & -0.0143 & 0.843 & 1.2 & -0.0277 & 0.683 & 1.2 & -0.0435 & 0.510 & 1.2 & -0.0515 & 0.436 & 1.2 & -0.0489 & 0.502 & 1.2 \\
\hline Stake\% & -0.0009 & 0.383 & 1.1 & -0.0012 & 0.260 & 1.2 & -0.0005 & 0.603 & 1.2 & -0.0003 & 0.800 & 1.2 & -0.0004 & 0.659 & 1.1 \\
\hline Log MV & -0.0327 & 0.051 & 1.4 & -0.0236 & 0.139 & 1.4 & -0.0186 & 0.227 & 1.4 & -0.0094 & 0.539 & 1.4 & -0.0320 & 0.056 & 1.3 \\
\hline Cash only & 0.0951 & 0.275 & 4.0 & 0.0919 & 0.313 & 4.3 & 0.1333 & 0.134 & 4.3 & 0.0840 & 0.342 & 4.3 & 0.0684 & 0.424 & 3.7 \\
\hline Cash w/ln alt & 0.1751 & 0.039 & 3.6 & 0.1254 & 0.158 & 4.0 & 0.2179 & 0.013 & 4.0 & 0.1902 & 0.029 & 4.0 & 0.2083 & 0.014 & 3.5 \\
\hline Equity only & -0.0566 & 0.821 & 1.1 & -0.1724 & 0.464 & 1.2 & -0.0428 & 0.852 & 1.2 & -0.1213 & 0.596 & 1.2 & -0.0528 & 0.835 & 1.1 \\
\hline Observations ${ }^{a}$ & 114 & & & 95 & & & 95 & & & 95 & & & 114 & & \\
\hline Adjusted $\mathrm{R}^{2}$ & $7.3 \%$ & & & $4.4 \%$ & & & $5.1 \%$ & & & $2.2 \%$ & & & $7.2 \%$ & & \\
\hline$F$-value & 1.74 & 0.069 & & 1.36 & 0.203 & & 1.42 & 0.172 & & 1.17 & 0.315 & & 1.74 & 0.070 & \\
\hline Park-test $F$-value & 0.39 & 0.964 & & 0.62 & 0.818 & & 0.59 & 0.844 & & 0.69 & 0.755 & & 0.60 & 0.837 & \\
\hline
\end{tabular}

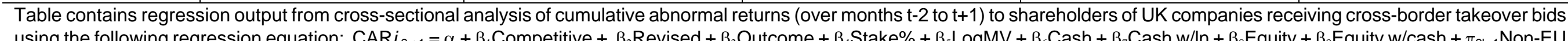

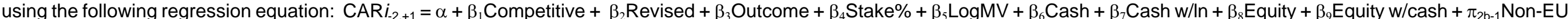

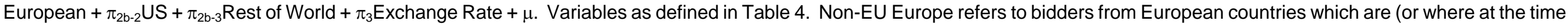

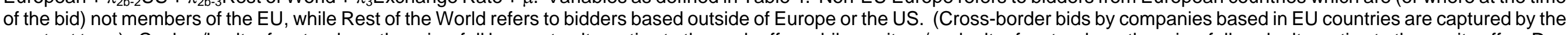

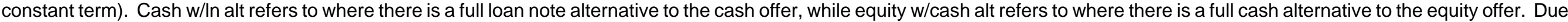

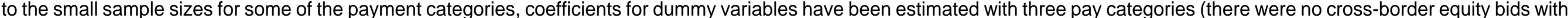

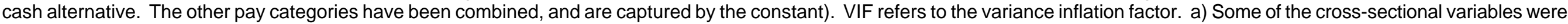

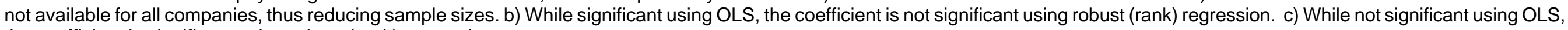
the coefficient is significant using robust (rank) regression. 